\title{
Hydrological connectivity from glaciers to rivers in the Qinghai-Tibet Plateau: roles of suprapermafrost and subpermafrost groundwater
}

\author{
Rui Ma ${ }^{1,2}$, Ziyong Sun ${ }^{1,2}$, Yalu Hu², Qixin Chang ${ }^{2}$, Shuo Wang ${ }^{2}$, Wenle Xing ${ }^{2}$, and Mengyan $\mathrm{Ge}^{2}$ \\ ${ }^{1}$ Laboratory of Basin Hydrology and Wetland Eco-restoration, China University of Geosciences, Wuhan, 430074, China \\ ${ }^{2}$ School of Environmental Studies, China University of Geosciences, Wuhan, 430074, China
}

Correspondence to: Rui Ma (rma@cug.edu.cn) and Ziyong Sun (ziyong.sun@cug.edu.cn)

Received: 5 January 2017 - Discussion started: 15 February 2017

Revised: 29 May 2017 - Accepted: 7 August 2017 - Published: 27 September 2017

\begin{abstract}
The roles of groundwater flow in the hydrological cycle within the alpine area characterized by permafrost and/or seasonal frost are poorly known. This study explored the role of permafrost in controlling groundwater flow and the hydrological connections between glaciers in high mountains and rivers in the low piedmont plain with respect to hydraulic head, temperature, geochemical and isotopic data, at a representative catchment in the headwater region of the Heihe River, northeastern Qinghai-Tibet Plateau. The results show that the groundwater in the high mountains mainly occurred as suprapermafrost groundwater, while in the moraine and fluvioglacial deposits on the planation surfaces of higher hills, suprapermafrost, intrapermafrost and subpermafrost groundwater cooccurred. Glacier and snow meltwaters were transported from the high mountains to the plain through stream channels, slope surfaces, and supraand subpermafrost aquifers. Groundwater in the Quaternary aquifer in the piedmont plain was recharged by the lateral inflow from permafrost areas and the stream infiltration and was discharged as baseflow to the stream in the north. Groundwater maintained streamflow over the cold season and significantly contributed to the streamflow during the warm season. Two mechanisms were proposed to contribute to the seasonal variation of aquifer water-conduction capacity: (1) surface drainage through the stream channel during the warm period and (2) subsurface drainage to an artesian aquifer confined by stream icing and seasonal frost during the cold season.
\end{abstract}

\section{Introduction}

Permafrost plays an important role in groundwater flow and thus hydrological cycles of cold regions (Walvoord et al., 2012). This is especially true for the mountainous headwaters of large rivers. In these areas interactive processes between permafrost and groundwater influence water resource management, engineering construction, biogeochemical cycling, and downstream water supply and conservation (Cheng and Jin, 2013). Study of groundwater in permafrost areas has been prompted by the need for water supplies, problems associated with groundwater in mining, and construction of buildings, highways, railways, airfields and pipelines. The ice features of permafrost areas and geological mapping are also of great interest (Woo, 2012).

In permafrost-dominated watersheds, hydrogeological regimes are primarily controlled by the distribution of frozen ground and taliks, as well as the freeze-thaw cycle of the active layer (White et al., 2007). Freezing alters the intrinsic behavior of aquifers because ground ice occupies interstitial voids and reduces the permeability of the water storage matrix (Woo, 2012). Thawing changes hydraulic connections between different water pools (Carey and Woo, 2000), further affecting the groundwater flow path and its interaction with surface water (e.g., Bense and Person, 2008; Carey and Quinton, 2005; Woo et al., 2008; Zhang et al., 2013). For example, groundwater-surface water interactions in Alaska were more commonly found in areas of discontinuous permafrost where hydraulic connections were spatially and temporally variable (e.g., Anderson et al., 2013; Minsley et al., 2012; Walvoord et al., 2012). At high latitudes, permafrost 


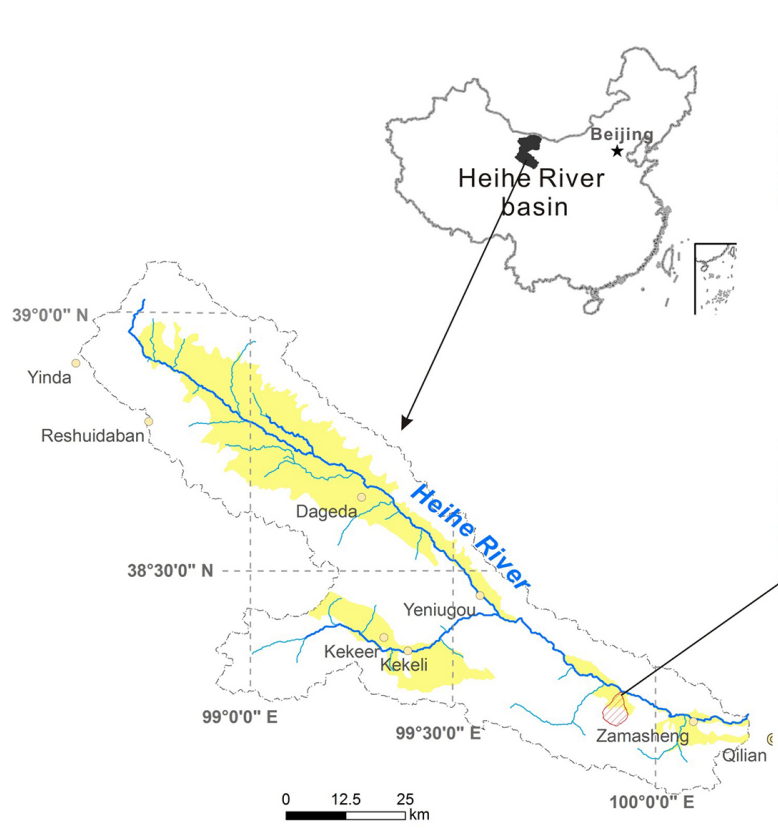

(a)

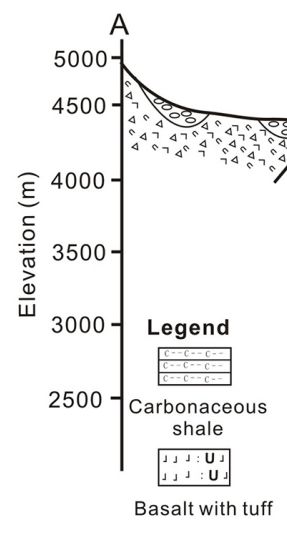

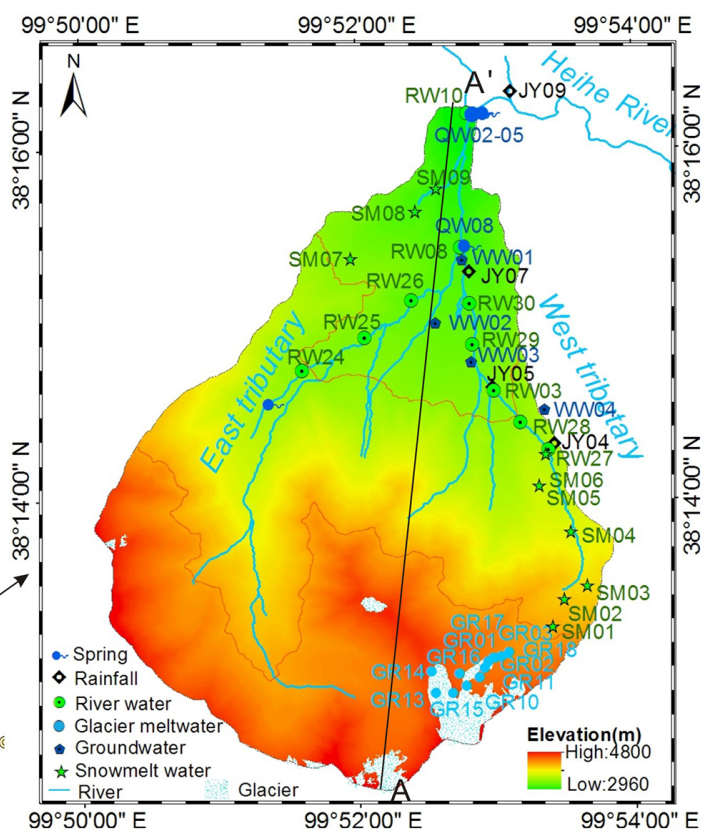

(b)

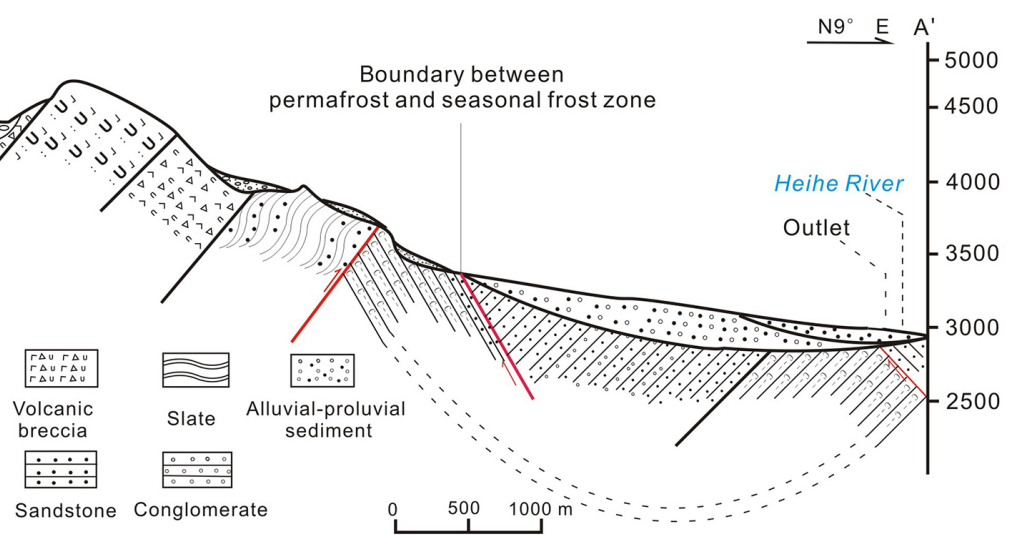

(c)

Figure 1. (a) Location of the headwater regions of the Heihe River and the distribution of unconsolidated deposits within the regions, (b) a map of the Hulugou catchment showing monitoring and sampling sites, and (c) a geological cross section.

distribution may affect lake density in addition to surface flow (Anderson et al., 2013). In areas of continuous permafrost, subpermafrost groundwater is often isolated from the surface, and there are unique mechanisms in thermokarst lake dynamics such as lateral expansion and breaching (Jones et al., 2011; Plug et al., 2008). Permafrost is now warming and thawing in many regions of the world (e.g., Anderson et al., 2013), and connections between permafrost degradation and local hydrologic changes have been established (e.g., O'Donnell et al., 2012; Yoshikawa and Hinzman, 2003).

Groundwater behavior in permafrost-dominated areas is becoming more important as permafrost, an effective barrier to recharge, continues to degrade (Walvoord and Striegl,
2007). However, permafrost hydrogeology studies have been limited to research on groundwater chemistry and modeling, mostly in northern latitude regions such as Alaska (USA), Canada, Siberia, Fennoscandia and Antarctica (e.g., Bense et al., 2009; Carey and Quinton, 2005; Evans et al., 2015; Ge et al., 2011; Woo et al., 2008). Fundamental knowledge gaps of groundwater systems in areas of permafrost still exist (Kane et al., 2013). Linkage between groundwater circulation and discharge has not been found in field studies, but simulations have shown a possible connection between changes in climate, groundwater movement, and increases in the winter low flows of northern Eurasian and northwestern North American rivers (Smith et al., 1991; Walvoord and Striegl, 2007). The quantitative substantiation of this link- 
age is challenging because hydrogeological and permafrost information is scarce in remote areas and regional-scale permafrost-hydrology interactions are complicated. Lack of hydrogeological information such as hydraulic head data, detailed hydrostratigraphy and groundwater age data impedes development of detailed models (Walvoord et al., 2012). Thus, a thorough understanding of groundwater flow systems in permafrost regions is a prerequisite for constructing advanced numerical modeling to quantitatively characterize groundwater flow and its interaction with surface water.

Because of the limited infrastructure and short field seasons, geochemical and isotopic tracers in samples from baseflow discharge and springs have been used to investigate recharge conditions and flow paths of groundwater in remote permafrost regions. For example, Stotler et al. (2009) illuminated the role of permafrost in deep flow system evolution, fluid movement and chemical evolution using hydrogeochemistry and ${ }^{2} \mathrm{H}$ and ${ }^{18} \mathrm{O}$ isotopes. Anderson et al. (2013) investigated the causes of lake area changes in the Yukon Flats, a region of discontinuous permafrost in Alaska, with ${ }^{2} \mathrm{H}$ and ${ }^{18} \mathrm{O}$ isotopes and found that about $5 \%$ of lake water came from snowmelt and/or permafrost thaw. Using stable isotopes $\left({ }^{18} \mathrm{O},{ }^{2} \mathrm{H}\right.$ and $\left.{ }^{13} \mathrm{C}_{\text {DIC }}\right)$ and noble gases, Utting et al. (2013) explored groundwater recharge and flow from permafrost watersheds in the western Arctic of Canada. Geochemical and isotopic data have proved useful in delineating the groundwater system and identifying flow paths in permafrost zones. However, the related research was mainly limited to arctic and subarctic river basins.

To better understand the effects of permafrost on groundwater flow and its interactions with surface water in mid- to low-latitude and high-altitude mountain areas, we selected the Hulugou catchment, which is a representative catchment in the headwater region of the Heihe River and covered by large areas of continuous and discontinuous permafrost and seasonal frost, as study site. The Heihe River is the second largest inland river in China with a drainage area of $\sim 150000 \mathrm{~km}^{2}$ (Fig. 1a). It provides water for domestic use, agriculture, and industry in the Qinghai, Gansu and Inner Mongolia provinces of northwestern China. The hydraulic head and temperature data obtained from newly drilled wells as well as geochemical and isotopic information were combined to (1) trace the recharge and flow paths of groundwater and (2) investigate the control of distribution and freezethaw processes of permafrost and seasonal frost on groundwater dynamics and groundwater-surface water interaction. It should be noted that moraine and fluvioglacial deposits are widely distributed on the planation surfaces of the higher hills in the headwater region of the Heihe River (Fig. 1a). However, their control on groundwater recharge and flow has not been studied. This is the first report on the occurrence of subpermafrost and intrapermafrost groundwater in the planation surface areas and on their hydraulic connectivity with groundwater in the seasonal frost zone and streams. Our results provide new insights into the hydrological function of
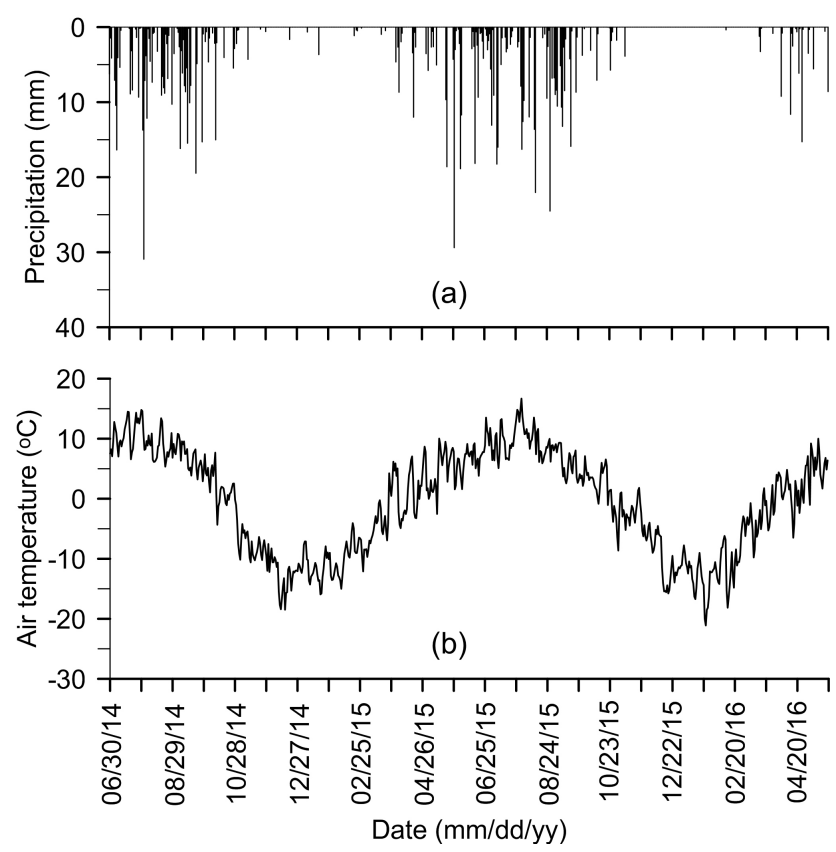

Figure 2. (a) Precipitation and (b) air temperature recorded at an elevation of 3649 ma.s.l. within the Hulugou catchment from June 2014 to April 2016.

planation surface area as a major reservoir for the storage and flow of groundwater in permafrost regions.

\section{Study area and background}

\subsection{General setting}

The Hulugou catchment has a drainage area of $23.1 \mathrm{~km}^{2}$ and is located within Qilian Mountains in the northeastern Qinghai-Tibet Plateau, between $38^{\circ} 12^{\prime} 14^{\prime \prime} \mathrm{N}$ and $38^{\circ} 16^{\prime} 23^{\prime \prime} \mathrm{N}$ latitude and $99^{\circ} 50^{\prime} 37^{\prime \prime} \mathrm{E}$ and $99^{\circ} 53^{\prime} 54^{\prime \prime} \mathrm{E}$ longitude (Fig. 1b). The elevation of the Hulugou catchment ranges between 2960 and $4820 \mathrm{~m}$, increasing from north to south. The slope ranges from 0 to $85^{\circ}$.

The catchment has a continental semiarid climate characterized by warm, rainy summers and cold, dry winters. From the plain to the high mountains, the mean annual precipitation ranges from 400 to $600 \mathrm{~mm}$, approximately $70 \%$ of which occurs during July-September (Fig. 2). In the high mountains with elevations from $\sim 3800$ to $4800 \mathrm{~m}$, most precipitation falls as snow. The annual potential evaporation is $1102 \mathrm{~mm}$. The mean annual temperature is $-3.9^{\circ} \mathrm{C}$, and the minimum and maximum temperatures are -25.2 and $25.8^{\circ} \mathrm{C}$, respectively. The daily precipitation and temperatures in the plain from 2014 through 2016 are shown in Fig. 2.

The catchment geomorphology is composed of high mountains, erosion hills, a piedmont sloping plain and a narrow gorge. High mountains in the southern part of the 
catchment contains five alpine glaciers, two ice lakes, and a range of classic glacial features such as U-shaped valleys, cirques, horn peaks, arêtes, moraines and talus slopes. The five glaciers have a total area of $0.827 \mathrm{~km}^{2}$ ( $\mathrm{Li}$ et al., 2014). The erosion hills are in the north, northeast and northwest of the catchment, with the planation surfaces on the top of the higher hills (3400-3800 m; Xu et al., 1989). The planation surfaces are underlain by permafrost, with typical permafrost-related features such as thermokarst ponds, frost mounds, permafrost bogs and permafrost plateaus. Cracks, terraces and landslides caused by active layer detachment slides are common on the upper slopes. The sloping plain is composed of several partially superimposed alluvial-pluvial fans. It is funnel-shaped, surrounded by the high mountains and hills, and connecting to the narrow gorge at the base, which leads into the Heihe River (Fig. 1c). The plain dips slightly toward the Heihe River with $2-3^{\circ}$ slopes.

The Hulugou stream is fed by the eastern and western tributary in front of the narrow gorge (Fig. 1b). Both tributaries and their branches originated from the high mountains are all ephemeral and fed mainly by glacier and snow meltwaters, ice lakes, and springs. From headwaters to the plain, they receive runoff from the subcatchments which are derived from precipitation. The tributaries are intermittently dry throughout the cold season (from October to May). Only the main stream in the narrow gorge is perennial, though it is ice-covered during winter.

\subsection{Hydrogeology}

Bedrock in the high mountains comprises lower Ordovician metamorphic and volcanic rock, including interbedded metasandstone and slate (Xu et al., 1989). Late Quaternary moraine deposits, derived primarily from these formations, are located at the front of the glaciers within cirques (Fig. 1c). The moraine is $5-30 \mathrm{~m}$ thick and consists of nonsorted, angular gravels and boulders. Scree deposits are also common in the high mountain area, and generally located at the foot of steep rock slopes or valley walls.

Bedrock in the erosion hills is composed of shales with limestone and sandstone (Xu et al., 1989). The slopes are generally covered with weathered residues of $0.5-3 \mathrm{~m}$ thickness but can also have local areas of exposed bedrock, talus material and silt deposits. The top of the higher hills, recognized as planation surfaces, are covered with middle and upper Pleistocene moraine and fluvioglacial deposits from several meters to tens of meters thick (Cao, 1977). Thin mud deposits are also found here, especially in thermokarst ponds, permafrost bogs and permafrost plateaus.

The surface geology in the piedmont sloping plain is primarily upper Pleistocene fluvioglacial deposits, which are mainly composed of poorly sorted, subangular, mud-bearing pebble gravels with erratic boulders. The underlying strata are glacial moraine and fluvioglacial deposits of the middle and lower Pleistocene series and conglomerates and sand- stones from the Cretaceous (Xu et al., 1989). The Holocene alluvial-proluvial deposits are only found on the bottom of the narrow gorge. Near the outlet of the Hulugou catchment, the upper Quaternary alluvial-proluvial deposits occur on the first to third terraces of the Heihe River.

The groundwater flows correspond to the topography, with a flow trend from south to north. According to previous regional hydrogeological investigations $(1: 200000$; Cao, 1977), permafrost in the headwater regions of the Heihe River mainly occurs in areas exceeding $3600 \mathrm{ma}$ a.s.l., and the groundwater in permafrost regions was conjectured to be suprapermafrost groundwater. Neither subpermafrost nor intrapermafrost groundwater has been reported. Our field investigation demonstrates that permafrost can be found as low as $3500 \mathrm{~m}$ a.s.l. in shady slopes. We found springs or seeps at the lower margin of the cirques containing moraine and scree deposits and at the upper slopes of the hills with fluvioglacial deposits on the top planation surfaces. Groundwater in the seasonal frost zone primarily occurred in fluvioglacial deposits of the sloping piedmont plain, as well as in the mountain scree deposits and slope deposits of the hills.

\section{Materials and methods}

\subsection{Field measurement}

Four cluster wells, WW01, WW02, WW03 and WW04, were installed in July and August 2014, for groundwater monitoring and sampling (locations shown in Fig. 1b). Each cluster included 3-4 wells with different interval screen depths. The screened intervals were 5, 10, 15 and $25 \mathrm{~m}$ underground for cluster WW01, 5, 10, 20 and $30 \mathrm{~m}$ underground for clusters WW02 and WW03, and 1.5, 12 and $24.3 \mathrm{~m}$ underground for cluster WW04. No water was found in wells within the WW02 cluster. Cluster wells WW01, WW02 and WW03 were located in the piedmont sloping plain dominated by seasonal frost, at elevations of 3144,3250 and $3297 \mathrm{~m}$, respectively. Cluster WW04 was located in a planation surface dominated by thermokarst ponds, frost mounds and permafrost bogs, at an elevation of $3501 \mathrm{~m}$.

During installation of each cluster well, temperature loggers (HOBO U20-001-02 temperature logger; Onset, Bourne, MA, USA) were buried in sediments at depths of $0.5,1,1.5,2,3,5,10,15$ (or 20) and 25 (or 30) $\mathrm{m}$ underground to monitor ground temperature. The ground temperature was recorded at intervals of $15 \mathrm{~min}$. Both groundwater table (if available) in the cluster wells and stream stage were measured using electronic pressure sensors (HOBO U20001-02 water level logger; Onset, Bourne, MA, USA). The sensor for stream water pressure measurement was installed in a stilling well to exclude waves and turbulence. Atmospheric pressure was measured simultaneously using a barometric pressure sensor (S-BPB-CM50; Onset, Bourne, MA, USA), so that differential pressure between water and atmo- 
spheric pressure could be calculated and then converted to the water table. The data were recorded every $15 \mathrm{~min}$ to be consistent with ground temperature measurements.

Five weather stations have been maintained by the Cold and Arid Regions Environmental and Engineering Research Institute, Chinese Academy of Sciences, since 2004 within the Hulugou catchment. These stations collect air temperature, humidity, precipitation and wind speed data at $30 \mathrm{~min}$ intervals (Chen et al., 2014). Data from the station on the sloping plain and the one near cluster WW04 ( 200 m away; similar elevation) were collected in this study.

\subsection{Water sampling and analysis}

For ion and isotope analysis, groundwater samples were collected from 12 wells between 2014 and 2016, and stream water samples were collected from 12 sites that were approximately evenly distributed from upstream to downstream between 2011 and 2016 (Fig. 1b). Both types of samples were collected at 7- to 14-day intervals during the warm season from June to September, but less frequently during the cold season. They were collected 3-4 times in January and 3-4 times in April. In addition to the 12 regularly sampled wells, groundwater was also irregularly sampled from 7 springs and 18 shallow wells with depth $<3 \mathrm{~m}$. Glacier meltwater was collected at 13 periglacial sites at elevations from 4261 to $4432 \mathrm{~m}$ between 2013 and 2015. Weekly precipitation (rainfall and/or snowmelt) was sampled from three sites that were distributed at about $200 \mathrm{~m}$ elevation intervals between 2012 and 2015.

When groundwater was collected from wells, appropriate well purging was done using a peristaltic pump before sampling. At all sampling times, $\mathrm{pH}$, electric conductivity (EC), temperature and dissolved oxygen concentration were measured in field using a portable Hatch $\mathrm{EC}$ and $\mathrm{pH}$ meter (HACH HQ40d), and alkalinity was determined on the sampling day using the Gran titration method (Gran, 1952). Seven water sample subsets were collected from each site and filtered with $0.22 \mu \mathrm{m}$ membranes in the field into polythene bottles that were thoroughly prewashed with deionized water. Samples for cation and minor element analysis were acidified with ultrapure $\mathrm{HNO}_{3}$ to $\mathrm{pH}=2$. All samples were wrapped with parafilm and stored at $4{ }^{\circ} \mathrm{C}$ before being transported to the laboratory.

All samples were analyzed for major ions, minor elements (Fe, $\mathrm{Si}$ and $\mathrm{Sr}$ ), ${ }^{18} \mathrm{O}$ and ${ }^{2} \mathrm{H}$ isotopic compositions, and ${ }^{13} \mathrm{C}$ isotopic compositions of DIC at the Laboratory of Basin Hydrology and Wetland Eco-restoration, China University of Geosciences (Wuhan). A total of 13 groundwater and spring samples were analyzed for ${ }^{3} \mathrm{H}$ concentrations and 7 were analyzed for ${ }^{14} \mathrm{C}$ activity. Anions $\left(\mathrm{SO}_{4}^{2-}, \mathrm{Cl}^{-}\right.$and $\left.\mathrm{NO}_{3}^{-}\right)$were determined using ion chromatography (IC; DX-120, Dionex, USA), while cations $\left(\mathrm{Ca}^{2+}, \mathrm{Mg}^{2+}, \mathrm{K}^{+}\right.$and $\left.\mathrm{Na}^{+}\right)$and some minor elements $(\mathrm{Fe}, \mathrm{Si}$ and $\mathrm{Sr})$ were determined by inductively coupled plasma-atomic emission spectrometry (ICP-
AES; IRIS INTRE II XSP) within 14 days after sampling. Ionic balance errors were $<5 \%$ for $84 \%$ of the samples and between 5.1 and $8 \%$ for the remaining samples.

Isotopic compositions of ${ }^{18} \mathrm{O}$ and ${ }^{2} \mathrm{H}$ were analyzed using an ultra-high precision isotopic water analyzer (L2130-I, Picarro, USA), and were expressed in $\delta$ per milliliter relative to the V-SMOW (Vienna Standard Mean Ocean Water), with precision of 0.025 and $0.1 \%$, respectively. The ${ }^{3} \mathrm{H}$ concentration was determined by the solid polymer electrolysis enrichment method with a tritium enrichment factor of 10 using an LSC-LB1 Liquid Scintillation Counter (Quantulus $1220^{\mathrm{TM}}$ ). The detection limit for the tritium measurement was approximately $\pm 1 \mathrm{TU}$. The ${ }^{3} \mathrm{H}$ values were reported in tritium units (TU).

The $\delta^{13} \mathrm{C}$ value of DIC in water samples was measured using a wavelength scanning cavity ring-down spectroscopy (WS-CRDS; G2131-I, Picarro, USA) and reported per milliliter relative to Vienna PeeDee Belemnite (V-PDB). The analytical precision for $\delta^{13} \mathrm{C}_{\mathrm{DIC}}$ was $0.1 \%$. For measuring ${ }^{14} \mathrm{C}$, water samples were treated first with $85 \%$ phosphoric acid and filtered to remove weathering carbonates. $\mathrm{CO}_{2}$ was purified and collected with a cryotrap, and then reduced to graphite using the $\mathrm{Zn} / \mathrm{Fe}$ method. Finally, ${ }^{14} \mathrm{C}$ activity was determined using an accelerator mass spectrometry (AMS; $3 \mathrm{MV}$, Tandetron) at the Xi'an AMS Center, China. The ${ }^{14} \mathrm{C}$ activity was reported as percent modern carbon $(\mathrm{pmC})$ and the analytical precision was $2 \%$.

\subsection{Sediment sampling and analysis}

Sediment samples were collected at 30 to $100 \mathrm{~cm}$ depth intervals when drilling the deepest borehole within each cluster. The subset for stable isotopic analyses was placed in an $8 \mathrm{~mL}$ borosilicate glass vial sealed with a Teflon-lined screw cap and parafilm and stored at $-20^{\circ} \mathrm{C}$. After being transported to the laboratory, water was extracted from the sediment samples using the cryogenic vacuum distillation technique and then measured for $\delta^{18} \mathrm{O}$ and $\delta^{2} \mathrm{H}$ (Smith et al., 1991; Sternberg et al., 1986). The measuring instrument, method and precision were the same as those noted above.

\subsection{The ${ }^{14} \mathrm{C}$ age model}

Along the groundwater flow path, the ${ }^{14} \mathrm{C}$ gained in soils is often diluted by geochemical reactions such as carbonate dissolution, exchange with the aquifer matrix and biochemical reactions. Therefore, when using the decay of ${ }^{14} \mathrm{C}_{\text {DIC }}$ as a measure of groundwater age, the dilution by nonatmospheric sources must first be corrected. Accounting for the dilution of ${ }^{14} \mathrm{C}$ caused by geochemical reaction, groundwater age is calculated using the following decay equations (Clark and Fritz, 1997):

$t=8267 \times \ln \left(\frac{q \times{ }^{14} \mathrm{C}_{0}}{{ }^{14} \mathrm{C}}\right)$, 
where $t$ is the groundwater age in years $\mathrm{BP},{ }^{14} \mathrm{C}$ is the measured ${ }^{14} \mathrm{C}$ activity, ${ }^{14} \mathrm{C}_{0}$ is the modern ${ }^{14} \mathrm{C}$ activity in the soil derived from DIC, and $q$ is the dilution factor.

Several models have been proposed to obtain the dilution factor (e.g., Mook, 1980; Pearson and Hanshaw, 1970; Tamers, 1975; Vogel, 1970, 1967; Vogel and Ehhalt, 1963). In this study, a $\delta^{13} \mathrm{C}$-mixing model modified by Clark and Fritz (1997) from the Pearson model (Pearson and Hanshaw, 1970) was applied to correct the ${ }^{14} \mathrm{C}$ dilution by carbonate dissolution. This model is based on variations in ${ }^{13} \mathrm{C}$ abundance, which differs significantly between the soil-derived DIC and carbonate minerals in the aquifer and is thus a good tracer of DIC evolution in groundwaters. The processes that add, remove or exchange carbon from the DIC pool and thereby alter the ${ }^{14} \mathrm{C}$ and ${ }^{13} \mathrm{C}$ concentrations will be accounted by the dilution factor $q$, which can be obtained from a ${ }^{13} \mathrm{C}$ mass balance:

$q=\frac{\delta^{13} \mathrm{C}_{\mathrm{DIC}}-\delta^{13} \mathrm{C}_{\mathrm{carb}}}{\delta^{13} \mathrm{C}_{\mathrm{rech}}-\delta^{13} \mathrm{C}_{\mathrm{carb}}}$

where $\delta^{13} \mathrm{C}_{\mathrm{DIC}}$ is the measured $\delta^{13} \mathrm{C}$ in groundwater, $\delta^{13} \mathrm{C}_{\text {carb }}$ is the $\delta^{13} \mathrm{C}$ of the calcite being dissolved (usually close to $0 \%$ ), and $\delta^{13} \mathrm{C}_{\text {rech }}$ is the initial $\delta^{13} \mathrm{C}$ of DIC in the infiltrating groundwater. The $\delta^{13} \mathrm{C}_{\text {rech }}$ was taken to be $-18 \%$, as suggested by Han et al. (2011) for northern China.

\section{Results}

\subsection{Sediments}

Well logs for clusters WW01, WW02 and WW03 indicate that the sediments in the seasonal frost area are mainly composed of sandy gravels which are highly permeable (Fig. 3). A silt clay layer with thickness between 3 and $6 \mathrm{~m}$ was found at all three sites and might extend throughout the sloping plain. The underlying bedrock was not revealed by the deepest boreholes at clusters WW01 and WW02, indicating that unconsolidated sediments are thicker than 25 and $30 \mathrm{~m}$ at the two sites. At cluster WW03, weathered sandstone was found at $22 \mathrm{~m}$ depth, indicating decreased thickness of unconsolidated sediments at the top of the sloping plain. These data suggest that the alluvial-pluvial deposits might accumulate on a slightly sloping shallow saucer-shaped basin, being the thickest at the center of the plain and becoming thinner towards its edges (Fig. 1c).

The sediments at cluster WW04 consist of a top clay layer to the depth of $2 \mathrm{~m}$, icy sandy gravel from 2 to $20 \mathrm{~m}$ and icefree sandy gravel at $20-25 \mathrm{~m}$ depth. There was a $0.2 \mathrm{~m}$ thick sandy clay layer at the depth of $12 \mathrm{~m}$ which was also ice free.

\subsection{Groundwater depth}

No water was found in any wells within cluster WW02 throughout the years, in the 5 and $10 \mathrm{~m}$ deep wells within

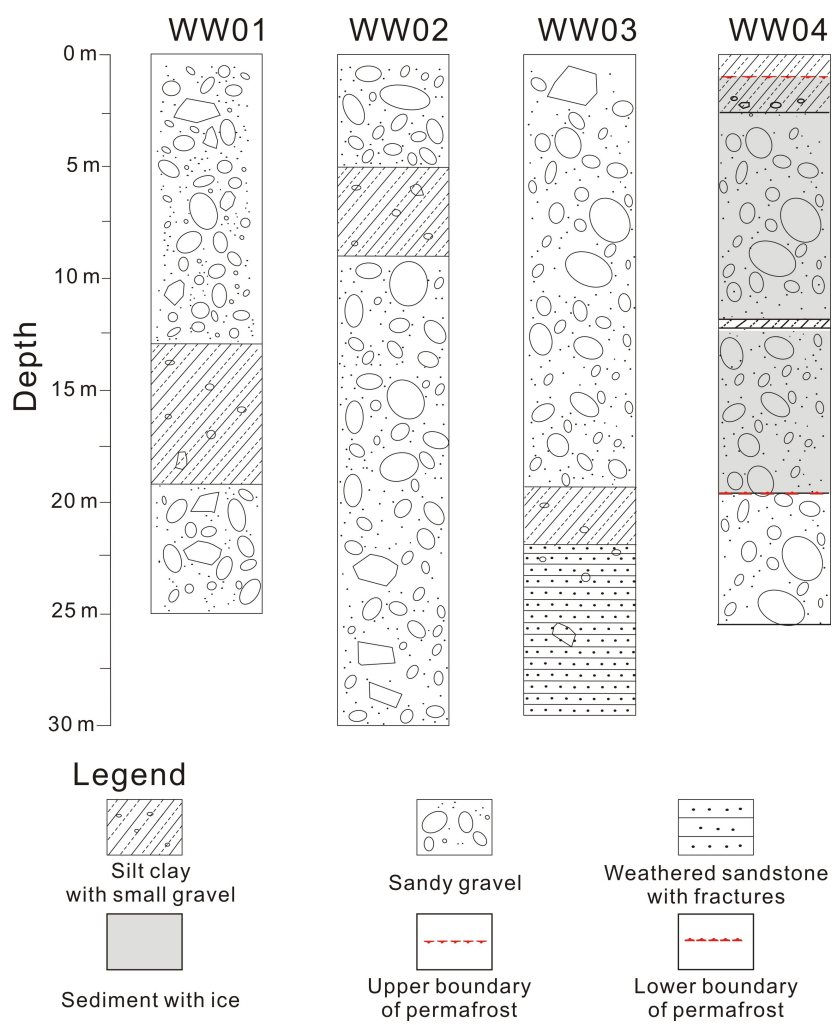

Figure 3. The well logs of the sediments for clusters WW01, WW02 and WW03 within the seasonal frost zone, as well as cluster WW04 within the permafrost zone.

cluster WW03 during cold season, or in the $12 \mathrm{~m}$ deep well within cluster WW04 at most times. Figure 4 shows the variation of groundwater depth over time from 2014 to 2016 in the wells with groundwater. The groundwater depth in the 20 and $30 \mathrm{~m}$ wells within cluster WW03 fluctuated between 13 and $18 \mathrm{~m}$ belowground during the warm, rainy season from mid-June to late October and declined and became stable in the cold, rainless season. The water table in the $20 \mathrm{~m}$ well was close to that in the $30 \mathrm{~m}$ well from late June to late July and higher than that for the rest of the time. The difference of water table between two wells ranged from $\sim 4 \mathrm{~m}$ in the cold season to $<1 \mathrm{~m}$ in the warm season. For cluster WW01, the groundwater depth in the $5 \mathrm{~m}$ well was comparatively stable with values between 4 and $5 \mathrm{~m}$ throughout the whole year, and that in the 10,15 and $25 \mathrm{~m}$ wells was $4-6 \mathrm{~m}$ belowground in the warm season but dropped dramatically to 5$19 \mathrm{~m}$ belowground in the cold season. Although the groundwater depth differed greatly between the cold and warm seasons, it was relatively stable during each of the two seasons. Similar to cluster WW03, the water table in the shallower well was always higher than that in the deeper well within cluster WW01, but the difference was much smaller during the warm season than the cold season.

The water table depth in the $1.5 \mathrm{~m}$ well at cluster WW04 was close to the ground surface from June to September and 

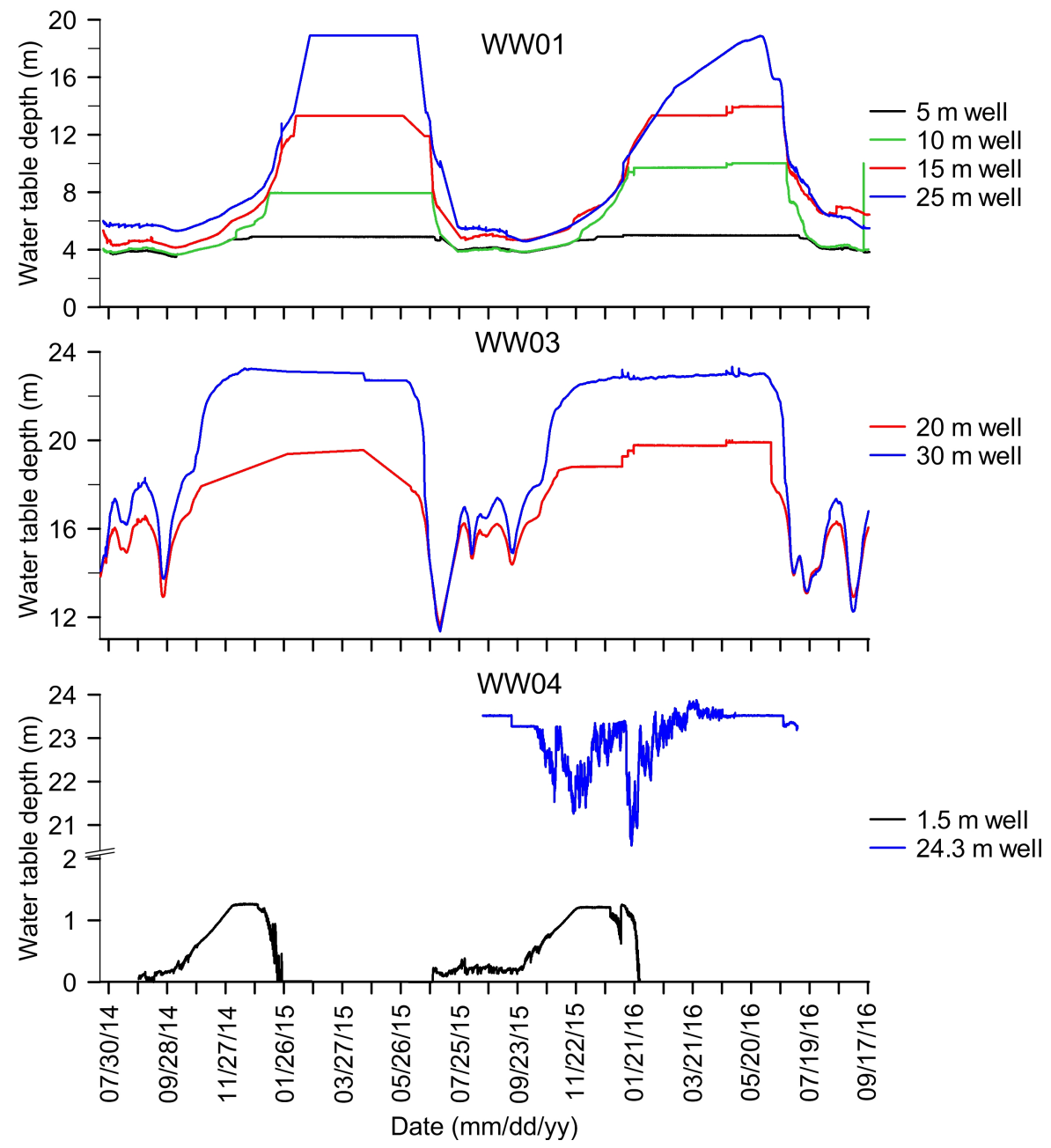

Figure 4. Time series of water table depth in the wells at cluster WW01, WW02 and WW04.

decreased to $1.5 \mathrm{~m}$ belowground from October to December. The groundwater depth in the $24.3 \mathrm{~m}$ well at cluster WW04 varied between 20.3 and $23.5 \mathrm{~m}$ belowground.

\subsection{Ground temperature}

The profiles in Fig. 5 show the intermonthly variation of ground temperature over a year from September 2014 to August 2015 at each cluster. The upper part of the profiles was influenced by seasonal heating and cooling from the land surface, showing significant seasonal changes in temperature. The temperature decreased at a gradually reduced rate with depth in the warm season and this was reversed in the cold season, which was presented as right-concave and leftconcave profiles in a temperature vs. depth graph, respectively. Two types of profiles converged at a critical depth where seasonal variation in temperature disappeared. The critical depth was about 7.5, 10 and $12 \mathrm{~m}$ belowground at the clusters WW03, WW02 and WW01, respectively, much deeper than that (only $\sim 2 \mathrm{~m}$ ) at cluster WW04.
However, a slightly dynamic variation in temperature was still observed below the critical depths at clusters WW01 and WW03. This was probably caused by the groundwater recharge or discharge processes, which is supported by comparing the temperature profiles among the four clusters. The dynamic variation in temperature was not found at depths between 10 and $30 \mathrm{~m}$ at cluster WW02, where groundwater depth exceeded $30 \mathrm{~m}$, nor at depths between 2 and $20 \mathrm{~m}$ at cluster WW04, where temperature remained almost constant $\sim 0{ }^{\circ} \mathrm{C}$ and thus groundwater was frozen throughout the year. A slightly seasonal variation in temperature was observed below $20 \mathrm{~m}$ at cluster WW04 with the pattern similar to that in the upper part of the profiles, i.e., increased temperatures in summer and decreased temperatures in winter.

The ground temperature profiles in the warm season did not intersect with the $0{ }^{\circ} \mathrm{C}$ isotherm at the clusters WW01, WW02 and WW03 (Fig. 5), confirming that these three clusters are in a seasonal frost zone. The seasonal frozen depth was about 2 and $2.5 \mathrm{~m}$ at clusters WW03 and WW02, shal- 

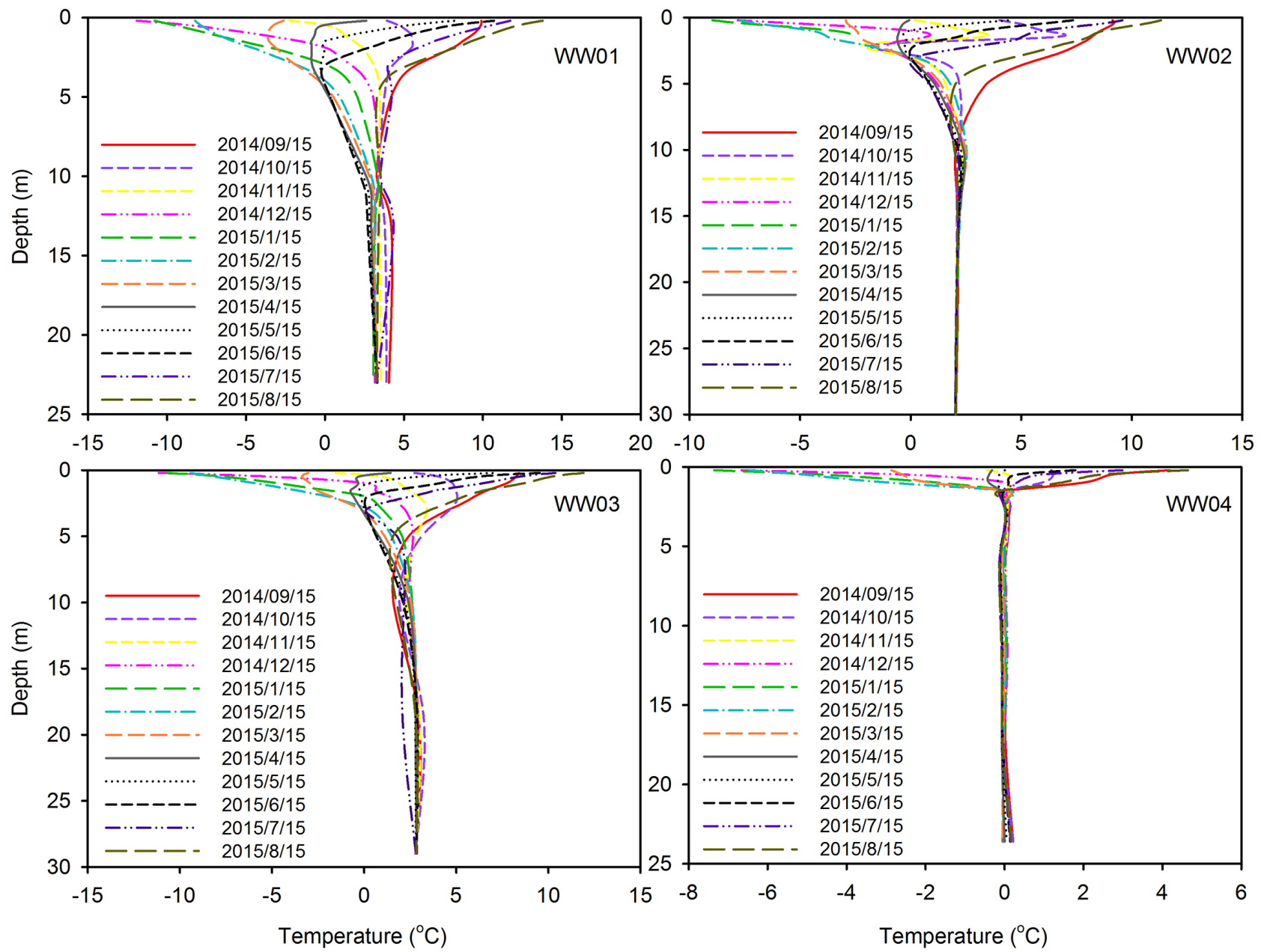

Figure 5. Temperature envelopes in the sediments at clusters WW01, WW02 and WW03 within the seasonal frost zone, as well as cluster WW04 within the permafrost zone.

lower than that $(3 \mathrm{~m})$ at cluster WW01. The active layer was $2 \mathrm{~m}$ thick at cluster WW04.

\subsection{Hydrogeochemistry}

The chemical compositions including major ions, minor elements ( $\mathrm{Si}$ and $\mathrm{Sr}$ ) and TDS for different types of water were listed in Table 2. The stream water concentrations had the seasonal variation. They exhibited the lowest values within the periglacial and permafrost zone, increased within the seasonal frost zone and further increased at the catchment outlet. Except for $\mathrm{NO}_{3}^{-}$and $\mathrm{SO}_{4}^{2-}$, other major ions and minor elements ( $\mathrm{Si}, \mathrm{Sr})$ concentrations as well as TDS were similar between the stream water at the catchment outlet and the groundwater in winter (Table 2 and Fig. 6). The spring waters exhibited minor changes in geochemistry over time.

The groundwaters sampled from the seasonal frost zone of the sloping plain (clusters WW01 and WW03) were $\mathrm{HCO}_{3} \cdot \mathrm{SO}_{4}-\mathrm{Ca} \cdot \mathrm{Mg}$ and $\mathrm{HCO}_{3} \cdot \mathrm{SO}_{4}-\mathrm{Mg} \cdot \mathrm{Ca}$ types, being slightly alkaline with a pH between 7.64 and 8.74 . The sam- ples at cluster WW01 had higher major ions and higher $\mathrm{Si}$, $\mathrm{Sr}$ and TDS concentrations than those at cluster WW03 (Table 1 and Figs. 6 and 7). The $\mathrm{Ca}^{2+}, \mathrm{Mg}^{2+}, \mathrm{NO}_{3}^{-}, \mathrm{SO}_{4}^{2-}, \mathrm{Sr}$ and TDS concentrations in groundwater at relatively shallow depths $(\leq 15 \mathrm{~m})$ were generally higher than those in the deeper parts of the aquifer $(>15 \mathrm{~m})$ at cluster WW01, whereas $\mathrm{Na}^{+}$and $\mathrm{K}^{+}$were higher in the deeper parts (Table 1 and Fig. 7). Among the groundwaters at cluster WW03, the $\mathrm{Ca}^{2+}, \mathrm{Mg}^{2+}, \mathrm{NO}_{3}^{-}, \mathrm{SO}_{4}^{2-}$, Sr and TDS concentrations in the $20 \mathrm{~m}$ well were highest, followed by those in the $30 \mathrm{~m}$ well, and then lowest in the $10 \mathrm{~m}$ well. The other parameters $\left(\mathrm{Mg}^{2+}, \mathrm{Cl}^{-}, \mathrm{HCO}_{3}^{-}\right.$and $\mathrm{Si}$ concentrations $)$ were similar at different depths within clusters WW01 or WW03.

At cluster WW04, the chemical type was $\mathrm{HCO}_{3}-\mathrm{Ca}$ for groundwater in the $1.5 \mathrm{~m}$ well, $\mathrm{HCO}_{3} \cdot \mathrm{SO}_{4}-\mathrm{Mg} \cdot \mathrm{Ca}$ for groundwater in the $24.3 \mathrm{~m}$ well and $\mathrm{HCO}_{3}-\mathrm{Ca} \cdot \mathrm{Na} \cdot \mathrm{Mg}$ for groundwater in the $12 \mathrm{~m}$ well. Among the stream water, thermokarst water and groundwaters, the groundwater in the $12 \mathrm{~m}$ well had the highest $\mathrm{Ca}^{2+}, \mathrm{Mg}^{2+}, \mathrm{K}^{+}, \mathrm{Na}^{+}, \mathrm{Si}, \mathrm{Sr}$, 
Table 1. Mean values and standard deviations $( \pm \mathrm{SD})$ of major ions and $\mathrm{Si}, \mathrm{Sr}$ and TDS concentrations in groundwater and stream water (in $\mathrm{mg} \mathrm{L}^{-1}$ ) within permafrost and seasonal frost zones. Number of samples used to calculate is also shown. All samples were collected from January 2014 to September 2015. "H" refers to high flows in the warm season, "L" refers to low flows in cold season, and "n.s." means that no samples were collected.

\begin{tabular}{|c|c|c|c|c|c|c|c|c|c|c|c|c|c|c|c|}
\hline \multicolumn{2}{|l|}{ Sampling information } & \multicolumn{2}{|c|}{$\begin{array}{c}\text { Number of } \\
\text { samples }\end{array}$} & \multicolumn{2}{|c|}{$\mathrm{Ca}^{2+}$} & \multicolumn{2}{|c|}{$\mathrm{Mg}^{2+}$} & \multicolumn{2}{|c|}{$\mathrm{Na}^{+}$} & \multicolumn{2}{|c|}{$\mathrm{K}^{+}$} & \multicolumn{2}{|c|}{$\mathrm{Sr}$} & \multicolumn{2}{|c|}{$\mathrm{Si}$} \\
\hline $\begin{array}{l}\text { Water type; } \\
\text { location }\end{array}$ & $\begin{array}{l}\text { Sample } \\
\text { site }\end{array}$ & $\mathrm{H}$ & $\mathrm{L}$ & $\mathrm{H}$ & $\mathrm{L}$ & $\mathrm{H}$ & $\mathrm{L}$ & $\mathrm{H}$ & $\mathrm{L}$ & $\mathrm{H}$ & $\mathrm{L}$ & $\mathrm{H}$ & $\mathrm{L}$ & $\mathrm{H}$ & $\mathrm{L}$ \\
\hline \multirow{3}{*}{$\begin{array}{l}\text { Stream water; } \\
\text { east tributary, } \\
\text { periglacial zone }\end{array}$} & RW27 & 18 & 2 & $28.5 \pm 3.9$ & $11.3 \pm 2.7$ & $15.6 \pm 2.3$ & $5.3 \pm 1.3$ & $1.6 \pm 0.4$ & $0.9 \pm 0.1$ & $0.5 \pm 0.1$ & $0.3 \pm 0$. & $\begin{array}{ll}1 & 0.2 \pm 0.0\end{array}$ & $0.1 \pm 0.0 \quad 0$. & $0.9 \pm 0.1$ & $0.2 \pm 0.0$ \\
\hline & RW28 & 15 & 2 & $27.9 \pm 2.7$ & $16.5 \pm 9.1$ & $15.2 \pm 1.5$ & $8.4 \pm 4.2$ & $1.6 \pm 0.5$ & $1.3 \pm 0.5$ & $0.5 \pm 0.2$ & $0.4 \pm 0$ & $.1 \quad 0.2 \pm 0.0$ & $0.1 \pm 0.0 \quad 0$. & $0.9 \pm 0.1$ & $0.3 \pm 0.3$ \\
\hline & RW03 & 15 & 0 & $27.3 \pm 2.6$ & n.s. & $14.5 \pm 1.7$ & n.s. & $1.5 \pm 0.4$ & n.s. & $0.4 \pm 0.1$ & n.s. & $0.2 \pm 0.0$ & $\begin{array}{ll}\text { n.s. } & 0 .\end{array}$ & $0.8 \pm 0.1$ & n.s. \\
\hline \multirow{2}{*}{$\begin{array}{l}\text { Stream water; } \\
\text { east tributary, } \\
\text { seasonal frost zone }\end{array}$} & RW29 & 17 & 2 & $34.0 \pm 7.3$ & $19.3 \pm 13.3$ & $20.7 \pm 6$ & $14.2 \pm 10.0$ & $2.5 \pm 1.2$ & $1.8 \pm 1.4$ & $0.6 \pm 0.1$ & $0.4 \pm 0.2$ & $\begin{array}{ll}2 & 0.2 \pm 0.1 \\
\end{array}$ & $0.1 \pm 0.1 \quad 1$. & $1.2 \pm 0.3$ & $0.4 \pm 0.3$ \\
\hline & RW30 & 15 & 0 & $33.6 \pm 9.6$ & n.s. & $20.0 \pm 6.9$ & n.s. & $2.4 \pm 1.3$ & n.s. & $0.5 \pm 0.1$ & n.s. & $0.2 \pm 0.1$ & n.s. 1 . & $1.1 \pm 0.2$ & n.s. \\
\hline \multirow{3}{*}{$\begin{array}{l}\text { Stream water; } \\
\text { west tributary, } \\
\text { seasonal frost zone }\end{array}$} & RW24 & 19 & 3 & $26.1 \pm 1.8$ & $32.5 \pm 14.4 \quad 12$ & $12.6 \pm 1.0$ & $16.7 \pm 5.9$ & $1.8 \pm 0.3$ & $2.1 \pm 0.6$ & $0.6 \pm 0.3$ & $0.7 \pm 0$ & $.4 \quad 0.1 \pm 0.0$ & $0.2 \pm 0.1 \quad 1$ & $1.1 \pm 0.1$ & $1.4 \pm 1.1$ \\
\hline & RW25 & 19 & 0 & $31.2 \pm 2.8$ & n.s. & $15.1 \pm 1.8$ & n.s. & $2.2 \pm 0.4$ & n.s. & $0.6 \pm 0.1$ & n.s. & $0.1 \pm 0.0$ & n.s. 1. & $1.2 \pm 0.1$ & n.s. \\
\hline & RW26 & 19 & 0 & $32.3 \pm 3.1$ & n.s. & $15.5 \pm 1.8$ & n.s. & $2.5 \pm 0.5$ & n.s. & $0.7 \pm 0.1$ & n.s. & $0.1 \pm 0.0$ & $\begin{array}{ll}\text { n.s. } & 1 .\end{array}$ & $1.2 \pm 0.1$ & n.s. \\
\hline \multirow{2}{*}{$\begin{array}{l}\text { Stream water; } \\
\text { catchment outlet, } \\
\text { seasonal frost zone }\end{array}$} & RW08 & 20 & 3 & $46.6 \pm 8.9$ & $60.2 \pm 37.7$ & $28.5 \pm 6.3 \quad 3$ & $39.3 \pm 23.2$ & $4.9 \pm 1.7$ & $9.7 \pm 6.9$ & $0.8 \pm 0.2$ & $1.2 \pm 0.8$ & $\begin{array}{ll}8 & 0.3 \pm 0.1\end{array}$ & $0.5 \pm 0.4 \quad 1$. & $1.6 \pm 0.2$ & $1.6 \pm 1.2$ \\
\hline & RW10 & 20 & 4 & $50.9 \pm 6.5$ & $76.7 \pm 11.2$ & $31.3 \pm 4.6$ & $36.6 \pm 4.3$ & $7.3 \pm 1.6$ & $26.2 \pm 12.2$ & $0.9 \pm 0.2$ & $1.6 \pm 0$. & $\begin{array}{ll}3 & 0.4 \pm 0.1\end{array}$ & $0.8 \pm 0.1 \quad 1$ & $1.8 \pm 0.2$ & $2.8 \pm 1.3$ \\
\hline \multirow{5}{*}{$\begin{array}{l}\text { Spring water; } \\
\text { seasonal frost } \\
\text { zone }\end{array}$} & QW02 & 19 & 4 & $59.3 \pm 4.1$ & $51.4 \pm 16.1$ & $36.7 \pm 1.7$ & $31.5 \pm 7.8$ & $14.1 \pm 0.8$ & $12.4 \pm 3.9$ & $1.4 \pm 0.2$ & $1.1 \pm 0$. & $\begin{array}{ll}.6 & 0.5 \pm 0.0\end{array}$ & $0.5 \pm 0.2 \quad 2$. & $2.3 \pm 0.2$ & $1.7 \pm 1.3$ \\
\hline & QW03 & 20 & 4 & $62.7 \pm 5.7$ & $48.6 \pm 14.1 \quad 37$ & $37.5 \pm 2.6$ & $30.3 \pm 8.0$ & $16.6 \pm 0.4$ & $13.4 \pm 6.2$ & $1.4 \pm 0.3$ & $1.0 \pm 0$ & $\begin{array}{ll}.5 & 0.6 \pm 0.0\end{array}$ & $0.5 \pm 0.2 \quad 2$. & $2.4 \pm 0.3$ & $1.9 \pm 1.0$ \\
\hline & QW04 & 20 & 4 & $64.5 \pm 5.1$ & $48.5 \pm 15.3 \quad 39$ & $39.0 \pm 2.3$ & $30.4 \pm 8.6$ & $18 \pm 0.3$ & $13.5 \pm 5.5$ & $1.5 \pm 0.3$ & $1.1 \pm 0$. & $\begin{array}{ll}6 & 0.6 \pm 0.0 \\
\end{array}$ & $0.5 \pm 0.2 \quad 2$ & $2.4 \pm 0.2$ & $1.8 \pm 1.2$ \\
\hline & QW05 & 20 & 4 & $65.5 \pm 7.3$ & $52.9 \pm 10.0 \quad 39$ & $39.7 \pm 3.2$ & $34.0 \pm 5.7$ & $19.1 \pm 0.5$ & $16.3 \pm 4.2$ & $1.5 \pm 0.3$ & $1.2 \pm 0$ & $\begin{array}{ll}.4 & 0.7 \pm 0.0\end{array}$ & $0.6 \pm 0.1 \quad 2$. & $2.6 \pm 0.8$ & $2.0 \pm 1.1$ \\
\hline & QW08 & 20 & 4 & $58.9 \pm 5.5$ & $44.6 \pm 15.2 \quad 36$ & $36.2 \pm 3.0$ & $28.2 \pm 8.2$ & $13 \pm 1.3$ & $8.0 \pm 2.6$ & $1.1 \pm 0.1$ & $0.9 \pm 0$. & $.5 \quad 0.6 \pm 0.0$ & $0.5 \pm 0.2 \quad 2$. & $2.3 \pm 0.2$ & $1.7 \pm 1.2$ \\
\hline \multirow{3}{*}{$\begin{array}{l}\text { Well water; } \\
\text { permafrost zone }\end{array}$} & WW04 (24.3 m) & 1 & 0 & 47.4 & n.s. & 22.9 & n.s. & 23.3 & n.s. & 6.4 & n.s. & 0.3 & n.s. & 1.3 & n.s. \\
\hline & WW04 (12 m) & 0 & 2 & n.s. & $204.6 \pm 1.4$ & n.s. & $95.9 \pm 1.3$ & n.s. & $221.0 \pm 10.4$ & n.s. & $9.7 \pm 1.8$ & n.s. & $2.7 \pm 0.1$ & n.s. & $9.1 \pm 0.2$ \\
\hline & WW04 (1.5 m) & 17 & 0 & $72.4 \pm 5.7$ & n.s. & $15.4 \pm 1.4$ & n.s. & $8.6 \pm 2.8$ & n.s. & $4.3 \pm 1.3$ & n.s. & $0.3 \pm 0.0$ & n.s. 3. & $3.9 \pm 0.3$ & n.s. \\
\hline Well water; & WW03 (30 m) & 19 & 4 & $55.1 \pm 11$ & $33.3 \pm 13.2 \quad 36$ & $36.7 \pm 6.3$ & $25.2 \pm 9.9$ & $17.6 \pm 15.1$ & $21.1 \pm 10.6 \quad 1$ & $1.6 \pm 0.9$ & $1.7 \pm 1$. & $.0 \quad 0.4 \pm 0.1$ & $0.3 \pm 0.1 \quad 1$. & $1.8 \pm 0.1$ & $1.2 \pm 1.2$ \\
\hline the top of the & WW03 (20 m) & 19 & 3 & $60.1 \pm 6.9$ & $57.0 \pm 9.6$ & $38.8 \pm 3.8$ & $35.6 \pm 7.2$ & $7.3 \pm 2.7$ & $6.7 \pm 1.3$ & $1.2 \pm 0.4$ & $1.4 \pm 0$ & $\begin{array}{ll}4 & 0.4 \pm 0.0\end{array}$ & $0.4 \pm 0.1 \quad 1$. & $1.9 \pm 0.2$ & $1.9 \pm 1.0$ \\
\hline $\begin{array}{l}\text { sloping plain, } \\
\text { seasonal frost zone }\end{array}$ & WW03(10m) & 6 & 0 & $46.5 \pm 11.8$ & n.s. & $5.7 \pm 13.1$ & n.s. & $9.4 \pm 6.8$ & n.s. & $4.7 \pm 5$ & n.s. & $0.3 \pm 0.1$ & n.s. 1. & $1.9 \pm 0.5$ & n.s. \\
\hline Well water; & WW01 (25 m) & 19 & 4 & $65.3 \pm 20.1$ & $31.4 \pm 4.3 \quad 43$ & $3.2 \pm 10.9$ & $20.7 \pm 9.9$ & $24.5 \pm 42.5$ & $14.5 \pm 7.7$ & $1.7 \pm 1.2$ & $1.3 \pm 0.8$ & $\begin{array}{ll}8 & 0.5 \pm 0.1\end{array}$ & $0.2 \pm 0.1 \quad 2$ & $2.2 \pm 0.3$ & $1.1 \pm 1.1$ \\
\hline the base of the & WW01 (15 m) & 19 & 4 & $67.1 \pm 15.7$ & $70.8 \pm 20.1 \quad 43$ & $43.8 \pm 9.6$ & $41.8 \pm 11.3$ & $13.2 \pm 18.1$ & $13.1 \pm 7.8$ & $1.4 \pm 0.7$ & $1.5 \pm 0$. & $\begin{array}{ll}7 & 0.5 \pm 0.1 \\
\end{array}$ & $0.5 \pm 0.1 \quad 2$ & $2.2 \pm 0.3$ & $1.6 \pm 0.9$ \\
\hline sloping plain, & WW01 $(10 \mathrm{~m})$ & 19 & 2 & $64.9 \pm 17.4$ & $80.8 \pm 3.6$ & $2.2 \pm 11.8$ & $34.4 \pm 4.8$ & $8.7 \pm 2.2$ & $6.6 \pm 1.3$ & $1.3 \pm 0.6$ & $0.7 \pm 0.2$ & $.2 \quad 0.4 \pm 0.1$ & $0.4 \pm 0.0$ & $2 \pm 0.4$ & $0.4 \pm 0.2$ \\
\hline seasonal frost zone & WW01 (5 m) & 12 & 0 & $76.6 \pm 8.4$ & n.s. & $48.9 \pm 4.8$ & n.s. & $9.0 \pm 1.0$ & n.s. & $1 \pm 0.1$ & n.s. & $0.5 \pm 0.1$ & n.s. 2 . & $2.1 \pm 0.1$ & n.s. \\
\hline Sampling informatio & & $\begin{array}{r}\text { Num } \\
\text { sam }\end{array}$ & & & $\mathrm{O}_{4}^{2-}$ & & $\mathrm{NO}_{3}^{-}$ & & $\mathrm{Cl}^{-}$ & & $\mathrm{HCO}$ & & & TDS & \\
\hline $\begin{array}{l}\text { Water type; } \\
\text { location }\end{array}$ & $\begin{array}{l}\text { Sample } \\
\text { site }\end{array}$ & $\mathrm{H}$ & $\mathrm{L}$ & $\mathrm{H}$ & $\mathrm{L}$ & $\mathrm{H}$ & $\mathrm{L}$ & $\mathrm{H}$ & $\mathrm{L}$ & $\mathrm{H}$ & & $\mathrm{L}$ & $\mathrm{H}$ & & $\mathrm{L}$ \\
\hline Stream water; & RW27 & 18 & 2 & $29.5 \pm 11$ & $32.9 \pm 13.6$ & $2.2 \pm 1.1$ & $1.4 \pm 0.6$ & $3.3 \pm 0.1$ & $7.3 \pm 0.9$ & $105.6=$ & $=13.2$ & $104.0 \pm 4.1$ & $134 \pm 16.7$ & & $.5 \pm 11.8$ \\
\hline east tributary, & RW28 & 15 & 2 & $31.7 \pm 8.3$ & $30.2 \pm 11.0$ & $2.5 \pm 0.9$ & $1.4 \pm 0.2$ & $3.1 \pm 0.3$ & $8.1 \pm 2.5$ & $102.1=$ & $=12.9$ & $107.3 \pm 5.5$ & $133.6 \pm 14.2$ & & $.0 \pm 30.1$ \\
\hline periglacial zone & RW03 & 15 & 0 & $31.2 \pm 8.9$ & n.s. & $2.6 \pm 0.9$ & n.s. & $3.3 \pm 0.2$ & n.s. & $101.2=$ & $=12.2$ & n.s. & $131.5 \pm 14.4$ & & n.s. \\
\hline Stream water; & RW29 & 17 & 2 & $45.3 \pm 16.6$ & $57.6 \pm 14.2$ & $2.9 \pm 1$ & $1.7 \pm 0.4$ & $3.4 \pm 0.4$ & $6.6 \pm 0.0$ & $131.4=$ & $=29.8$ & $133.6 \pm 9.9$ & $175.1 \pm 44.9$ & & $.6 \pm 44.4$ \\
\hline $\begin{array}{l}\text { east tributary, } \\
\text { seasonal frost zone }\end{array}$ & RW30 & 15 & 0 & $46.8 \pm 27.1$ & n.s. & $3 \pm 1.2$ & n.s. & $3.3 \pm 0.4$ & n.s. & $125.1=$ & $=33.2$ & n.s. & $172.1 \pm 61.0$ & & n.s. \\
\hline Stream water; & RW24 & 19 & 3 & $28.7 \pm 8.4$ & $73.3 \pm 14.8$ & $2.7 \pm 0.6$ & $1.9 \pm 0.4$ & $3.5 \pm 0.2$ & $3.9 \pm 0.2$ & $96 \pm$ & & $122.7 \pm 5.8$ & $124.2 \pm 11.5$ & & $.5 \pm 34.0$ \\
\hline west tributary, & RW25 & 19 & 0 & $41.4 \pm 10.1$ & n.s. & $3.1 \pm 0.7$ & n.s. & $3.7 \pm 0.2$ & n.s. & $108.5=$ & $=11.5$ & n.s. & $151.6 \pm 17.6$ & & n.s. \\
\hline seasonal frost zone & RW26 & 19 & 0 & $44.7 \pm 10.6$ & n.s. & $3.2 \pm 0.7$ & n.s. & $3.6 \pm 0.3$ & n.s. & $108 \pm$ & 9.5 & n.s. & $156.7 \pm 18$ & & n.s. \\
\hline Stream water; & RW08 & 20 & 3 & $92 \pm 30$ & $207.9 \pm 107.0$ & $\begin{array}{ll}0 & 3.9 \pm 1.2\end{array}$ & $3.1 \pm 1.1$ & $3.7 \pm 0.4$ & $5.2 \pm 0.6$ & 166.3 & \pm 30 & $240.0 \pm 85.6$ & $263.6 \pm 61.2$ & 446. & $8 \pm 218.8$ \\
\hline $\begin{array}{l}\text { catchment outlet, } \\
\text { seasonal frost zone }\end{array}$ & RW10 & 20 & 4 & $106.4 \pm 23.8$ & $246.1 \pm 71.0$ & $4 \pm 1.1$ & $2.7 \pm 0.7$ & $4 \pm 0.4$ & $6.9 \pm 2.3$ & $178.8=$ & $=25.7$ & $238.0 \pm 4.5$ & $294.4 \pm 47.5$ & & $1 \pm 89.7$ \\
\hline Spring water; & QW02 & 19 & 4 & $126.1 \pm 27.7$ & $162.1 \pm 31.1$ & $1 \quad 4.2 \pm 1.4$ & $2.8 \pm 0.4$ & $4.9 \pm 0.5$ & $5.5 \pm 0.4$ & $222.3=$ & $=12.8$ & $230.7 \pm 2.6$ & $358 \pm 31.4$ & & $4 \pm 22.7$ \\
\hline seasonal frost & QW03 & 20 & 4 & $137.3 \pm 43.6$ & $152.7 \pm 26.8$ & $8 \quad 4.1 \pm 1.6$ & $2.6 \pm 0.7$ & $5 \pm 0.7$ & $5.3 \pm 0.7$ & $233.1=$ & $=13.9$ & $238.8 \pm 3.4$ & $381.2 \pm 50.9$ & & $4 \pm 56.8$ \\
\hline zone & QW04 & 20 & 4 & $150.1 \pm 34.1$ & $156.0 \pm 20.0$ & $4.2 \pm 1.4$ & $2.8 \pm 0.4$ & $5.6 \pm 0.6$ & $5.4 \pm 0.4$ & $237.7=$ & $=10.7$ & $240.3 \pm 4.7$ & $401.9 \pm 38$ & & $.2 \pm 48.6$ \\
\hline & QW05 & 20 & 4 & $150.9 \pm 34.2$ & $147.7 \pm 39.1$ & $14.2 \pm 1.5$ & $5.3 \pm 6.6$ & $5.5 \pm 0.6$ & $5.3 \pm 0.8$ & $243.4=$ & $=11.2$ & $248.7 \pm 5.5$ & $408.4 \pm 37.2$ & & $3 \pm 53.8$ \\
\hline & QW08 & 20 & 4 & $95.4 \pm 33.2$ & $107.5 \pm 37.1$ & $1 \quad 4.3 \pm 1.8$ & $2.4 \pm 1.0$ & $4.4 \pm 0.5$ & $4.6 \pm 0.7$ & $254.8=$ & $=14.1$ & $246.1 \pm 6.0$ & $340.8 \pm 40.3$ & & $.5 \pm 61.1$ \\
\hline Well water; & WW04 (24.3 m) & 1 & 0 & 64.7 & n.s. & 1.5 & n.s. & 17.6 & n.s. & 237 & & n.s. & 302.9 & & n.s. \\
\hline permafrost zone & WW04 (12 m) & 0 & 2 & n.s. & $4.1 \pm 0.0$ & n.s. & $0.2 \pm 0.2$ & n.s. & $106.4 \pm 10.4$ & $\mathrm{n}$. & & $833.6 \pm 30.2$ & n.s. & 105 & $9.3 \pm 40.6$ \\
\hline & WW04 (1.5 m) & 17 & 0 & $10.2 \pm 5.5$ & n.s. & $0.3 \pm 1.1$ & n.s. & $6.1 \pm 1.1$ & n.s. & $294.3=$ & $=25.7$ & n.s. & $264.6 \pm 18.2$ & & n.s. \\
\hline Well water; & WW03 (30 m) & 19 & 4 & $115 \pm 16.8$ & $74.9 \pm 24.6$ & $3.8 \pm 1.3$ & $0.1 \pm 0.1$ & $4.5 \pm 0.9$ & $4.9 \pm 0.3$ & $243.8=$ & $=24.9$ & $282.4 \pm 14.7$ & $356.4 \pm 29.6$ & & $6 \pm 52.1$ \\
\hline the top of the & WW03 (20 m) & 19 & 3 & $116.2 \pm 31.7$ & $148.8 \pm 26.5$ & $4 \pm 1.5$ & $2.4 \pm 0.4$ & $4 \pm 0.5$ & $5.1 \pm 0.4$ & $236.1=$ & $=31.4$ & $250.2 \pm 9.0$ & $349.7 \pm 41.3$ & & $3 \pm 42.1$ \\
\hline $\begin{array}{l}\text { sloping plain, } \\
\text { seasonal frost zone }\end{array}$ & WW03(10m) & 6 & 0 & $122.4 \pm 64.2$ & n.s. & $3.6 \pm 0.7$ & n.s. & $5 \pm 1.1$ & n.s. & $297.8 \pm$ & 136.3 & n.s. & $409.5 \pm 196.4$ & & n.s. \\
\hline Well water; & WW01 (25 m) & 19 & 4 & $158.9 \pm 51.6$ & $92.4 \pm 22.0$ & $4.9 \pm 2.4$ & $0.7 \pm 0.7$ & $5.2 \pm 2.7$ & $5.1 \pm 0.4$ & 270.6 & \pm 43 & $212.1 \pm 32.5$ & $439.2 \pm 95.9$ & & $.5 \pm 61.0$ \\
\hline the base of the & WW01 (15 m) & 19 & 4 & $162.4 \pm 33.6$ & $212.3 \pm 70.9$ & $5.5 \pm 2$ & $2.8 \pm 0.9$ & $4.8 \pm 1.1$ & $5.0 \pm 0.2$ & $255 \pm$ & 42.2 & $287.6 \pm 58.4$ & $425.9 \pm 78.2$ & 491. & $3 \pm 126.7$ \\
\hline sloping plain, & WW01 (10 m) & 19 & 2 & $150.5 \pm 52.6$ & $267.7 \pm 26.6$ & $\begin{array}{ll}5 & 5.3 \pm 2.1\end{array}$ & $2.6 \pm 0.2$ & $4.7 \pm 0.7$ & $5.1 \pm 0.4$ & $243.2=$ & $=54.6$ & $332.2 \pm 2.7$ & $399.4 \pm 109.3$ & & $1 \pm 35.9$ \\
\hline seasonal frost zone & WW01 (5m) & 12 & 0 & $172.6 \pm 33.2$ & n.s. & $6.9 \pm 1.2$ & n.s. & $4.5 \pm 0.3$ & n.s. & $269.4=$ & $=23.9$ & n.s. & $454.3 \pm 58$ & & n.s. \\
\hline
\end{tabular}




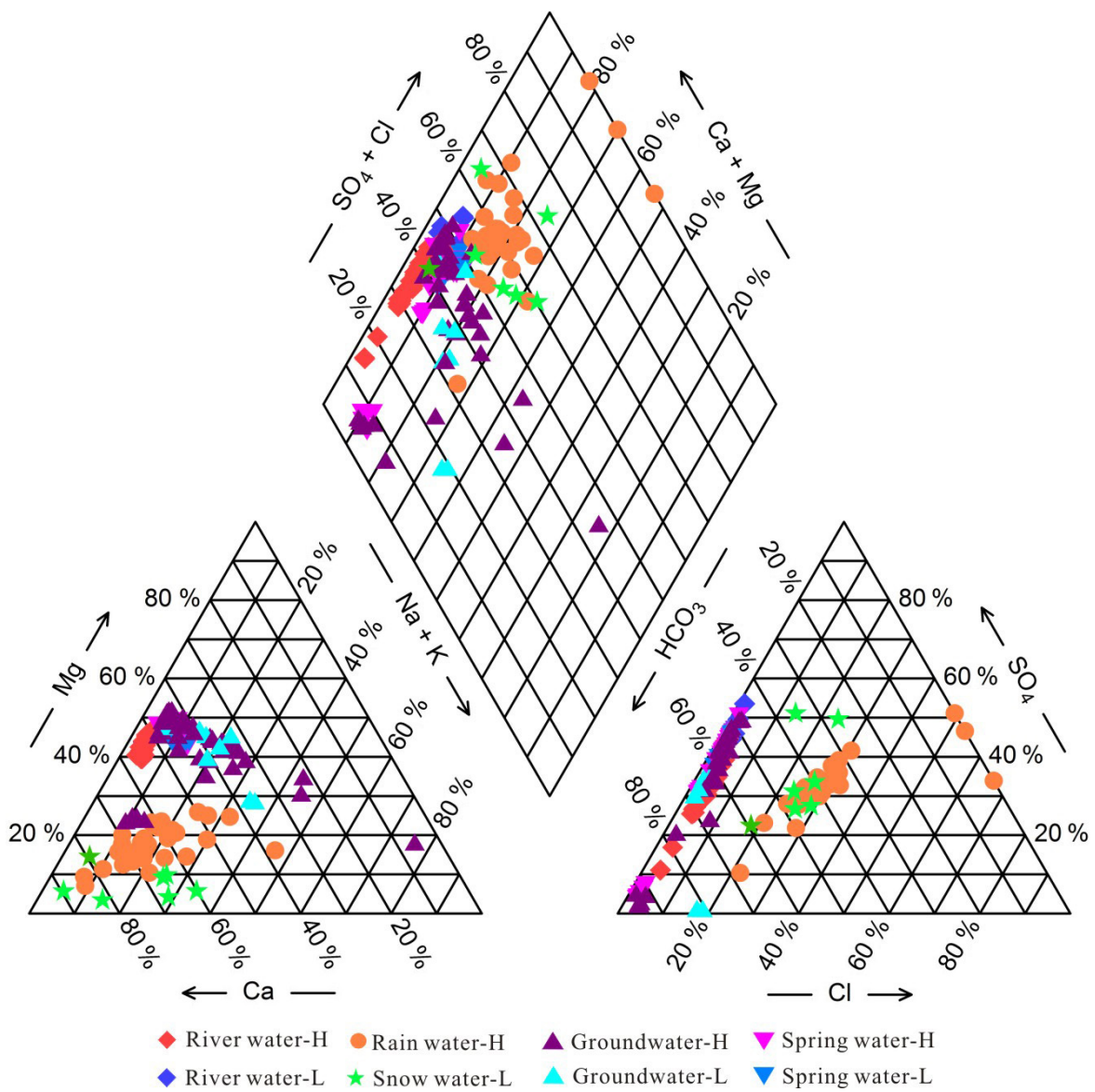

Figure 6. The piper diagram for groundwater, stream water, precipitation, and glacier and snow meltwater in the study area. " $H$ " refers to high flows in the warm season; "L" refers to low flows in cold season.

Table 2. The ${ }^{3} \mathrm{H},{ }^{13} \mathrm{C}$ and ${ }^{14} \mathrm{C}$ isotopic composition of groundwater samples and ${ }^{14} \mathrm{C}$ ages corrected using the $\delta^{13} \mathrm{C}$-mixing model modified by Clark and Fritz (1997); "n.d.” means not determined, and "n.c.” means not calculated.

\begin{tabular}{|c|c|c|c|c|c|c|c|c|c|}
\hline \multirow[t]{2}{*}{ Sample site } & \multirow[t]{2}{*}{$\begin{array}{r}{ }^{3} \mathrm{H} \\
(\mathrm{TU})\end{array}$} & \multicolumn{2}{|c|}{$\delta^{13} \mathrm{C}(\% \circ)$} & \multicolumn{2}{|c|}{$\begin{array}{c}{ }^{14} \text { C activity } \\
(\mathrm{pmC})\end{array}$} & \multicolumn{2}{|c|}{$\begin{array}{l}\text { Uncorrected } \\
{ }^{14} \mathrm{C} \text { age }\end{array}$} & \multicolumn{2}{|r|}{$\begin{array}{l}\text { Corrected } \\
{ }^{14} \mathrm{C} \text { age }\end{array}$} \\
\hline & & $\delta^{13} \mathrm{C}$ & $\begin{array}{l}\text { Error } \\
(1 \sigma)\end{array}$ & $\begin{array}{r}{ }^{14} \mathrm{C} \\
\text { activity }\end{array}$ & $\begin{array}{l}\text { Error } \\
(1 \sigma)\end{array}$ & $\begin{array}{r}\text { Age } \\
\text { (years) }\end{array}$ & $\begin{array}{l}\text { Error } \\
(1 \sigma)\end{array}$ & $q$ & $\begin{array}{l}\text { Age } \\
\text { (years) }\end{array}$ \\
\hline WW04 (24.3 m well) & n.d. & -16.77 & 0.51 & 76.43 & 0.32 & 2159 & 34 & 0.90 & 1637 \\
\hline WW04 (1.5 m well) & 15.11 & -13.60 & 0.57 & 96.34 & 0.31 & 299 & 26 & 0.76 & -2009 (modern) \\
\hline WW03 (30 m well) & 19.38 & -8.79 & 0.57 & 51.77 & 0.22 & 5288 & 33 & 0.49 & -483 (modern) \\
\hline WW03 (20 m well) & 16.22 & n.d. & n.d. & n.d. & n.d. & n.c. & n.c. & n.c. & n.c. \\
\hline QWIP01 (spring) & 20.69 & -8.31 & 0.61 & 35.51 & 0.17 & 8317 & 39 & 0.46 & 2170 \\
\hline QWIP02 (spring) & 17.33 & -8.05 & 0.55 & 49.60 & 0.20 & 5632 & 32 & 0.45 & -856 (modern) \\
\hline WW01 (25 m well) & 16.95 & -5.92 & 0.53 & 44.38 & 0.18 & 6525 & 33 & 0.33 & -2477 (modern) \\
\hline WW01 (15 m well) & 24.18 & n.d. & n.d. & n.d. & n.d. & n.c. & n.c. & n.c. & n.c. \\
\hline WW01 (10 m well) & 16.20 & n.d. & n.d. & n.d. & n.d. & n.c. & n.c. & n.c. & n.c. \\
\hline QW02 (spring) & 27.83 & n.d. & n.d. & n.d. & n.d. & n.c. & n.c. & n.c. & n.c. \\
\hline QW03 (spring) & 13.84 & n.d. & n.d. & n.d. & n.d. & n.c. & n.c. & n.c. & n.c. \\
\hline QW05 (spring) & 43.59 & n.d. & n.d. & n.d. & n.d. & n.c. & n.c. & n.c. & n.c. \\
\hline QW04 (spring) & 13.61 & -5.09 & 0.70 & 43.05 & 0.19 & 6770 & 34 & 0.28 & -3475 (modern) \\
\hline QW08 (spring) & 18.58 & n.d. & n.d. & n.d. & n.d. & n.c. & n.c. & n.c. & n.c. \\
\hline
\end{tabular}




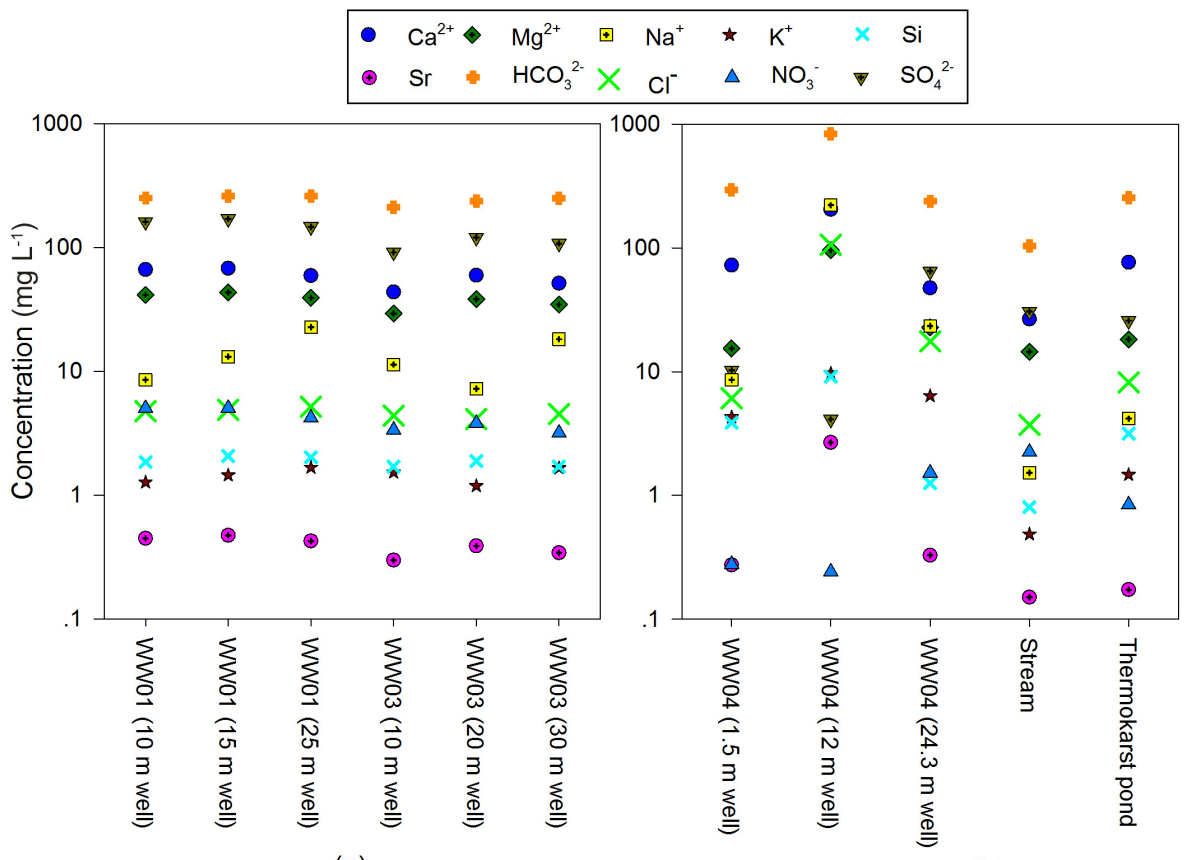

(a)

(b)

Figure 7. (a) Groundwater chemistry at different depths of the two clusters within the seasonal frost zone and (b) chemistry of groundwater, stream water and thermokarst pond water within the permafrost zone. WW01, WW03 and WW04 are symbols for clusters. The number in brackets means the specific screen depth of wells. Note the log scale on the $y$ axis.

$\mathrm{Cl}^{-}, \mathrm{HCO}_{3}^{-}$and TDS concentrations and the lowest $\mathrm{SO}_{4}^{2-}$ and $\mathrm{NO}_{3}^{-}$concentrations. The groundwater in the $24.3 \mathrm{~m}$ well had the higher $\mathrm{K}^{+}, \mathrm{Na}^{+}, \mathrm{Mg}^{2+}, \mathrm{Sr}, \mathrm{Cl}^{-}, \mathrm{SO}_{4}^{2-}, \mathrm{NO}_{3}^{-}$and TDS concentrations but lower $\mathrm{Ca}^{2+}$ and $\mathrm{HCO}_{3}^{-}$concentrations than in the $1.5 \mathrm{~m}$ well. The groundwater in permafrost zones generally had lower $\mathrm{SO}_{4}^{2-}, \mathrm{Mg}^{2+}$ and TDS concentrations but higher $\mathrm{Cl}^{-}$and $\mathrm{K}^{+}$concentrations than groundwaters in the seasonal frost zone. Other chemical parameters were similar between the groundwaters within the two zones.

\subsection{Stable isotopes}

A local meteoric water line (LMWL) fitted to the ${ }^{2} \mathrm{H}$ and ${ }^{18} \mathrm{O}$ isotopic compositions of precipitation at the study area is $\delta^{2} \mathrm{H}=8.5 \delta^{18} \mathrm{O}+22.6\left(r^{2}=0.9886, n=120\right.$; Fig. 8$)$, similar to that $\left(\delta^{2} \mathrm{H}=8.3 \delta^{18} \mathrm{O}+17.1\right)$ reported by Tong et al. (2016) at a weather station near the Hulugou catchment outlet. The $\delta^{18} \mathrm{O}$ of glacier meltwater samples was between -10 and $-7.6 \%$, while the $\delta^{2} \mathrm{H}$ was between -60 and $-35 \%$. The stream waters had $\delta^{18} \mathrm{O}$ values between -12.3 and $-6.7 \%$ and $\delta^{2} \mathrm{H}$ values between -88.5 and $-31.6 \%$, most of which overlapped with those of groundwaters from the seasonal frost zone (Fig. 8).

The water and/or ice extracted from sediment cores at depths $<5 \mathrm{~m}$ belowground at cluster WW04 exhibited relatively enriched ${ }^{2} \mathrm{H}$ and ${ }^{18} \mathrm{O}$, with compositions between -50 and $-10 \%$ and between -8 and $-2 \%$, respectively (Fig. 9). All samples from these depths fell below the LMWL and could be statistically defined by the regression line $\delta^{2} \mathrm{H}=$ $6.17 \delta^{18} \mathrm{O}+2.99\left(r^{2}=0.98, n=35\right)$ with the slope less than that of LMWL (Fig. 8), indicating the occurrence of evaporation. By comparison, the $\delta^{2} \mathrm{H}$ and $\delta^{18} \mathrm{O}$ of extracted water and ice at depths between 5 and $20 \mathrm{~m}$ were relatively depleted, with average values of -50 and $-9.5 \%$, respectively (Fig. 9), which were similar to those of glacier meltwater. Most of the samples at these depths fell on the LMWL, indicating a precipitation origin without significant evaporation (Fig. 8). At the depth $>20 \mathrm{~m}$, the ${ }^{2} \mathrm{H}$ and ${ }^{18} \mathrm{O}$ isotopes became enriched again in the extracted water and ice, with $\delta^{2} \mathrm{H}$ values between -55 and $-25 \%$ and $\delta^{18} \mathrm{O}$ values between -8 and $-2 \%$. These samples fell on a line with a slope of 5.1 .

The change of $\delta^{2} \mathrm{H}$ and $\delta^{18} \mathrm{O}$ in groundwaters with depth at cluster WW04 was similar to that in extracted water and ice from sediments. The ${ }^{2} \mathrm{H}$ and ${ }^{18} \mathrm{O}$ were most enriched in the groundwater from the $1.5 \mathrm{~m}$ well, less enriched in the groundwater from the $24.3 \mathrm{~m}$ well and most depleted in the groundwater from the $12 \mathrm{~m}$ well (Fig. 8). All groundwater samples at cluster WW04 fell below the LMWL and the $\delta^{2} \mathrm{H}$ and $\delta^{18} \mathrm{O}$ values of groundwater from the $12 \mathrm{~m}$ well were similar to those of the glacier meltwaters.

The groundwater samples collected from clusters WW01 and WW03 fell along the LMWL, and their $\delta^{18} \mathrm{O}$ and $\delta^{2} \mathrm{H}$ values were similar to those in the glacier meltwaters (Fig. 8). The groundwater samples at cluster WW01 exhibited more negative $\delta^{2} \mathrm{H}$ and $\delta^{18} \mathrm{O}$ values than those at cluster WW03. 


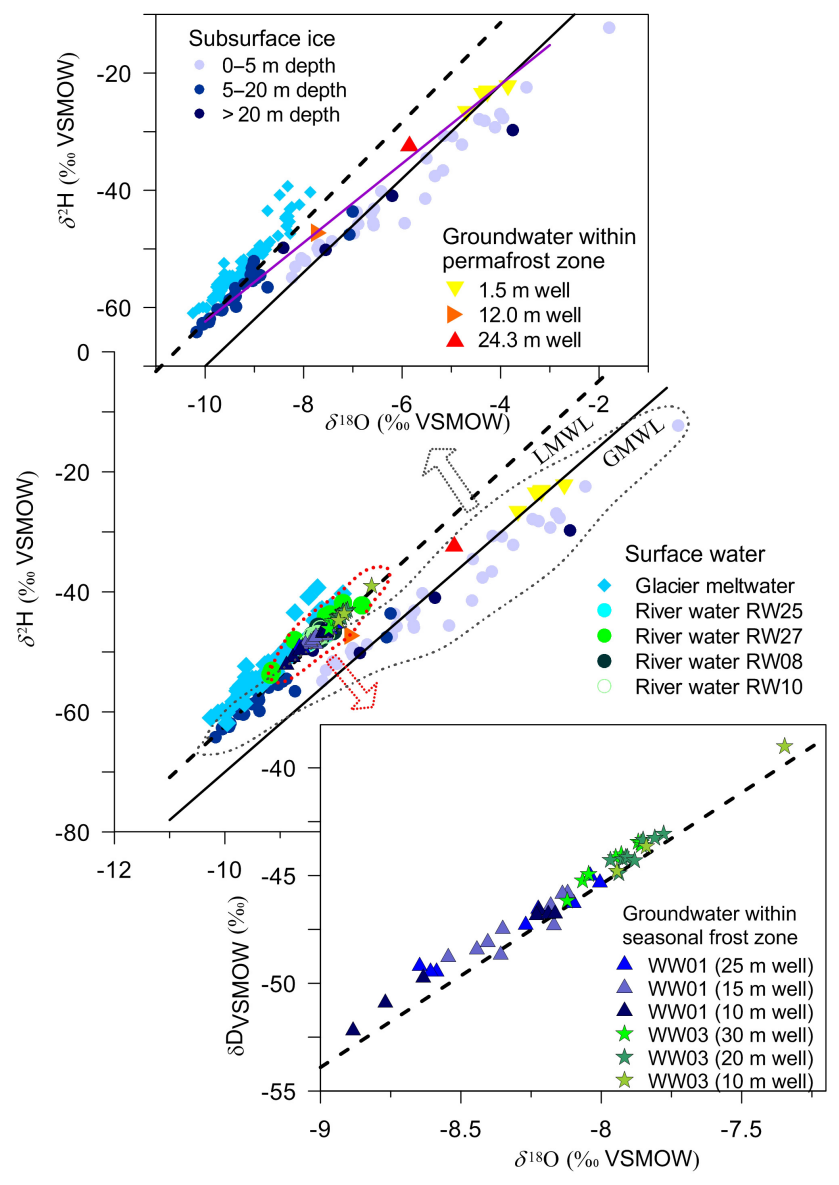

Figure 8. The $\delta^{18} \mathrm{O}$ and $\delta^{2} \mathrm{H}$ relationship for different water types collected from September 2014 to August 2015, as well as for water and ice extracted from sediment cores at cluster WW04.

The $\delta^{2} \mathrm{H}$ and $\delta^{18} \mathrm{O}$ values were close at different depths from late July to October, but had a general depletion trend with depth at both clusters for the rest of the year (Fig. 10). Both the magnitude and seasonal variation of $\delta^{18} \mathrm{O}$ and $\delta^{2} \mathrm{H}$ were similar between the groundwater and stream water. However, spring water showed much smaller variation in $\delta^{18} \mathrm{O}$ and $\delta^{2} \mathrm{H}$ compared to the groundwater and stream water.

\subsection{Radioactive isotopes and groundwater age}

The ${ }^{3} \mathrm{H}$ concentrations were $15.11 \mathrm{TU}$ in the groundwater from the $1.5 \mathrm{~m}$ well at cluster WW04, between 16.20 and $24.18 \mathrm{TU}$ in the groundwater at clusters WW01 and WW03, and between 13.61 and $43.59 \mathrm{TU}$ in the springs in the sloping plain (Table 2). Except for one spring sample (QW05), the ${ }^{3} \mathrm{H}$ concentrations of all samples were $<30 \mathrm{TU}$, indicating that the groundwater was recharged by recent precipitation and some "bomb" related ${ }^{3} \mathrm{H}$ is possibly presented (Zhai et al., 2013). Along with flow path, the $\delta^{13} \mathrm{C}_{\text {DIC }}$ in groundwaters increased from the permafrost zone with values between -13.6 and $-16.77 \%$ o to the top of the sloping plain with a value of $-8.79 \%$, and further to the base of the sloping plain with a value of $-5.09 \%$ (Table 2). Opposite to the ${ }^{13} \mathrm{C}_{\text {DIC }}$ trend, the ${ }^{14} \mathrm{C}$ activity decreased from permafrost zone with values between 76.43 and $96.34 \mathrm{pmC}$ to the top of the sloping plain with a value of $51 \mathrm{pmC}$, and further to the base of the sloping plain with a value of $44 \mathrm{pmC}$ (Table 2). The groundwater in the $24.3 \mathrm{~m}$ well at cluster WW04 had a relatively old corrected ${ }^{14} \mathrm{C}$ age of $1627 \mathrm{yr}$. The other groundwaters exhibited negative corrected ${ }^{14} \mathrm{C}$ ages, indicating that they were derived from modern precipitation (Clark and Fritz, 1997).

\section{Discussion}

\subsection{Exchange and pathways of groundwater in the permafrost zone}

The groundwater in the $1.5 \mathrm{~m}$ well at cluster WW04 occurred within the active layer and thus was recognized as suprapermafrost groundwater, which was previously reported in the study area (Cao, 1977). Within the permafrost layer with

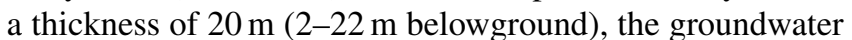
was found in a talik at the depths between 12 and $12.2 \mathrm{~m}$ (in the $12 \mathrm{~m}$ well). It was considered as intrapermafrost groundwater. The underlying subpermafrost groundwater in the $24.3 \mathrm{~m}$ well was observed in the field, which was further evidenced by the slightly increased temperature and the distinct hydrogeochemistry. The intra- and subpermafrost groundwater had not been reported before this study.

\subsubsection{Suprapermafrost groundwater}

The $\delta^{2} \mathrm{H}$ and $\delta^{18} \mathrm{O}$ values, ${ }^{3} \mathrm{H}$ concentration, and shallow groundwater depth suggest that suprapermafrost groundwater was mainly recharged by recent local precipitation via vertical seepage. The widespread thermokarst ponds and organic cover with high porosity favor water entry into the suprapermafrost reservoir. The $\delta^{2} \mathrm{H}$ and $\delta^{18} \mathrm{O}$ values at the intersection between the evaporation line of suprapermafrost groundwater and LMWL were similar to those of glacier and snow meltwater, suggesting that glacier and snow meltwater was another recharge source (Fig. 8). Given that cluster WW04 is located on the lowest of three ladder-like terraces, the suprapermafrost groundwater may also be recharged by the lateral flow from the aquifer located on a higher terrace.

The terrace on which cluster WW04 is located adjoins two opposite hill slopes to the west and east, respectively, and a hill slope connecting to the northern plain (Fig. 1c). At the shoulder of the three slopes, the moraine and fluvioglacial sediments become thinner and finally end at the upper slope. Thus, except for evapotranspiration, much of the suprapermafrost groundwater flowed to the adjacent slopes covered by thin weathered residues, and was mainly discharged into streams as baseflow, or onto the surface as seeps and springs and from there into streams. This not only explains why many springs and seeps were found on the up- 


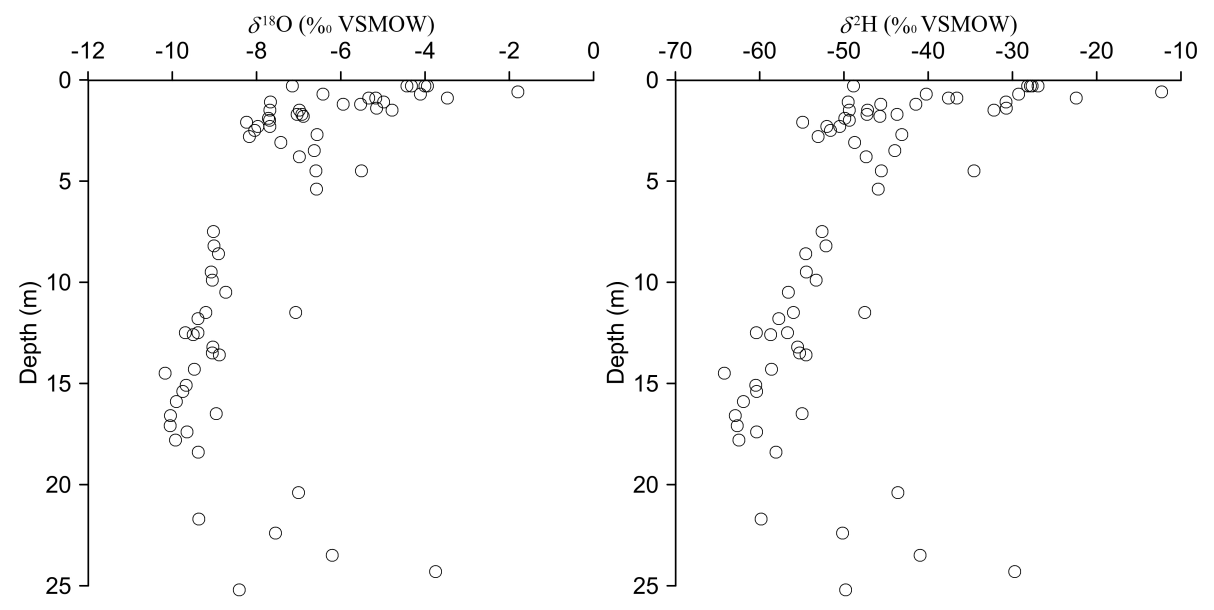

Figure 9. The variation of $\delta^{18} \mathrm{O}$ and $\delta^{2} \mathrm{H}$ in water and ice extracted from sediment cores with depth at cluster WW04.

per slopes of the hills whose upper planation surfaces were covered with moraine and fluvioglacial sediments, but also was one of major reasons why streams increased progressively in volume from headwaters to the sloping plain. Where weathered residues are continuous along the slope and have a coarse grain size, the suprapermafrost groundwater can be discharged into these residues, then flow through them to the talus fan at the base of the hill and, finally, drain into the aquifers in the sloping plain. Our field investigation demonstrated that another discharge way of suprapermafrost groundwater was leakage to the subpermafrost aquifer through sinkholes created by thawing and collapse of the permafrost (Fig. 11).

The low TDS, $\mathrm{Cl}^{-}$and $\mathrm{Na}^{-}$concentrations and the $\mathrm{HCO}_{3}-\mathrm{Ca}$ water type suggest that the suprapermafrost groundwater had experienced insufficient water-rock interaction, probably caused by a relatively short residence time or flow path. This is further supported by the highest ${ }^{14} \mathrm{C}$ activity in the suprapermafrost groundwater among all samples (Table 2), which is $96.34 \mathrm{pmC}$, and by a $15.11 \mathrm{TU}{ }^{3} \mathrm{H}$ concentration which is close to the atmospheric value and thus an indicator of modern water (Zhai et al., 2013). Though occurring on a relatively flat planation surface, the suprapermafrost groundwater was actually easy to drain because the planation surface adjoins the lower slopes in three directions. In addition, the suprapermafrost aquifer is fairly thin and rich in organic matter with high permeability. Therefore, the suprapermafrost groundwater may have a high renewal rate. The enriched ${ }^{2} \mathrm{H}$ and ${ }^{18} \mathrm{O}$ isotopes indicate that suprapermafrost groundwater had also experienced a certain degree of evaporation (Fig. 8). These two conclusions are not contradictory given the high local evaporation and shallow suprapermafrost groundwater depth. The shallow groundwater depth may also result in very short flow paths for the majority of the waters and relatively short contact time for chemical reactions be- tween the water and the soils (Frey et al., 2007; Stotler et al., 2009; Vonk et al., 2015).

The recharge of suprapermafrost groundwater varied seasonally. It mainly occurred during the warm season because glacier melting and precipitation were concentrated during this period. Meanwhile, the active layer underwent thawing. Recharge was limited in the cold season because recharge sources were frozen and active layer freezing obstructed infiltration (Woo, 2012). The discharge of suprapermafrost groundwater exhibited a corresponding seasonal cycle. An examination of groundwater depth and temperature data indicates that the storage of suprapermafrost groundwater also varied significantly throughout the warm seasons. This was not only a result of variation in the thawed depth of the active layer, but also related to the frequent conversion of the recharge-discharge interrelationship. During the late spring when the active layer was beginning to thaw and the storage capacity of suprapermafrost reservoir was still small, the water table was close to the surface though the recharge was limited. In the summer, though the seasonal thaw moved downward and thus the storage capacity of suprapermafrost reservoir increased, the groundwater rose further and exfiltrated over the land surface to support bogs and thermokarst ponds. This is because the recharge was so intensive that it exceeded the discharge capacity of the aquifer. The water table began to decline in October and dropped to $1.2 \mathrm{~m}$ belowground by December, leading to the drying of bogs and thermokarst ponds. This was caused by a reverse of the recharge-discharge interrelationships: by late October, glaciers were frozen and local precipitation was also minimal, but the discharge passages of suprapermafrost aquifer, located on hill slopes at relatively lower altitudes, remained unfrozen. Consequently, the discharge exceeded the recharge during this period, resulting in the drainage of suprapermafrost groundwater and the decline of water table. 

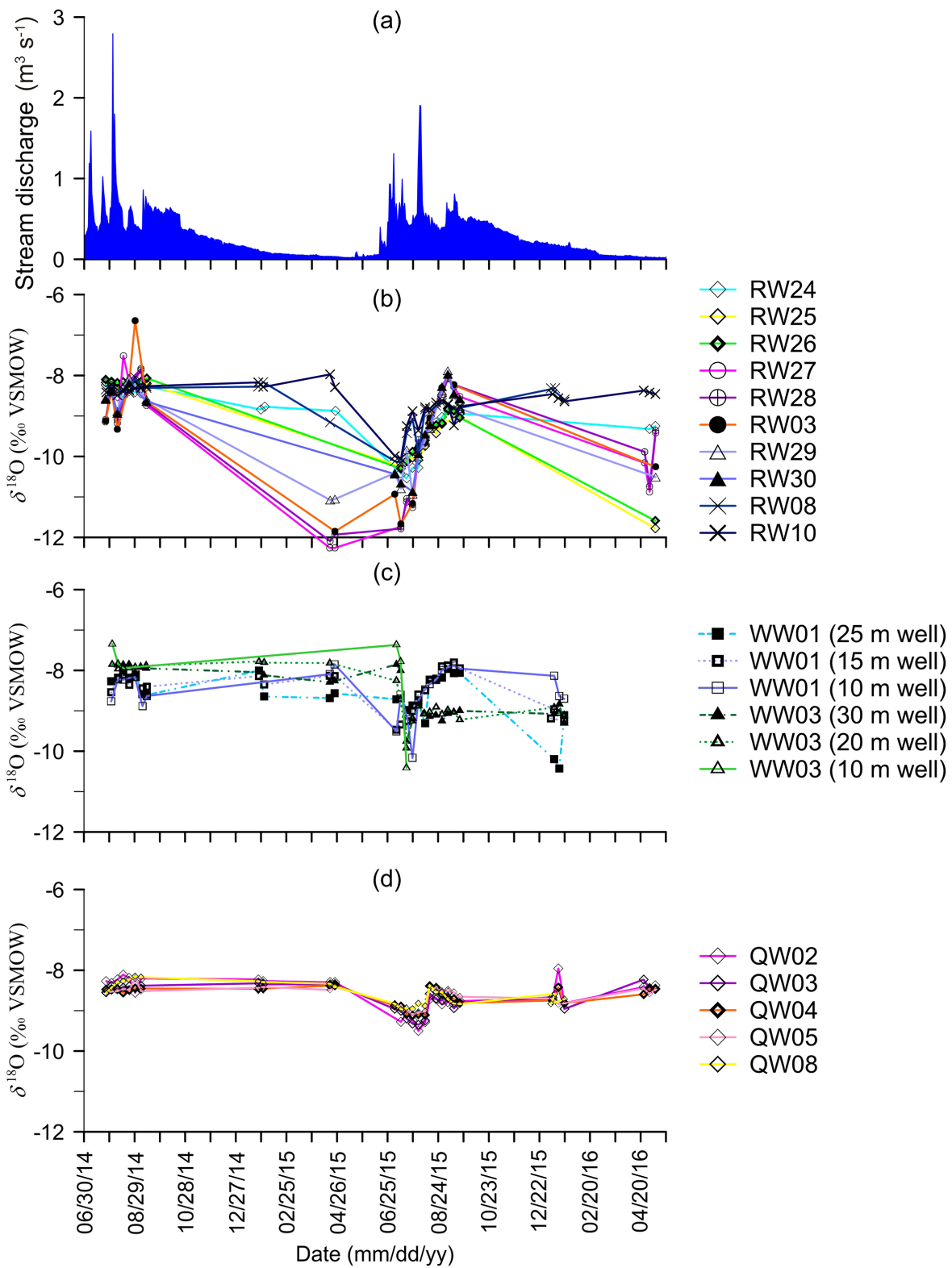

Figure 10. Time series of the Hulugou stream discharge (a) and the $\delta^{18} \mathrm{O}$ in stream water (b), well water (c) and spring water (d).

\subsubsection{Subpermafrost groundwater}

The recharge from superficial water pools such as suprapermafrost aquifer and thermokarst ponds to the subpermafrost aquifer was suggested by the similar seasonal change in temperature between the supra- and subpermafrost groundwaters, although the amplitude of temperature change in subpermafrost groundwater was much smaller (Fig. 5). Our field investigation revealed that the sinkholes resulting from thawing and collapse of permafrost serve as passages between supra- and subpermafrost aquifers (Fig. 11a). However, the recharge amount from suprapermafrost aquifer should be limited since the subpermafrost groundwater had different geochemical characteristics, more depleted ${ }^{2} \mathrm{H}$ and ${ }^{18} \mathrm{O}$ isotopes and older ${ }^{14} \mathrm{C}$ age in comparison with suprapermafrost groundwater.

The weaker evaporation and stronger water-rock interaction for subpermafrost groundwater, inferred by more depleted ${ }^{2} \mathrm{H}$ and ${ }^{18} \mathrm{O}$ compositions and higher TDS and major ion concentrations than in suprapermafrost groundwater, suggest a second recharge source. This source should occur in a colder environment and thus be depleted in isotope composition and experience a longer flow path and residence time for chemical reactions. On the $\delta^{2} \mathrm{H}$ vs. $\delta^{18} \mathrm{O}$ plot, the subpermafrost groundwaters fell between meltwater and suprap- 


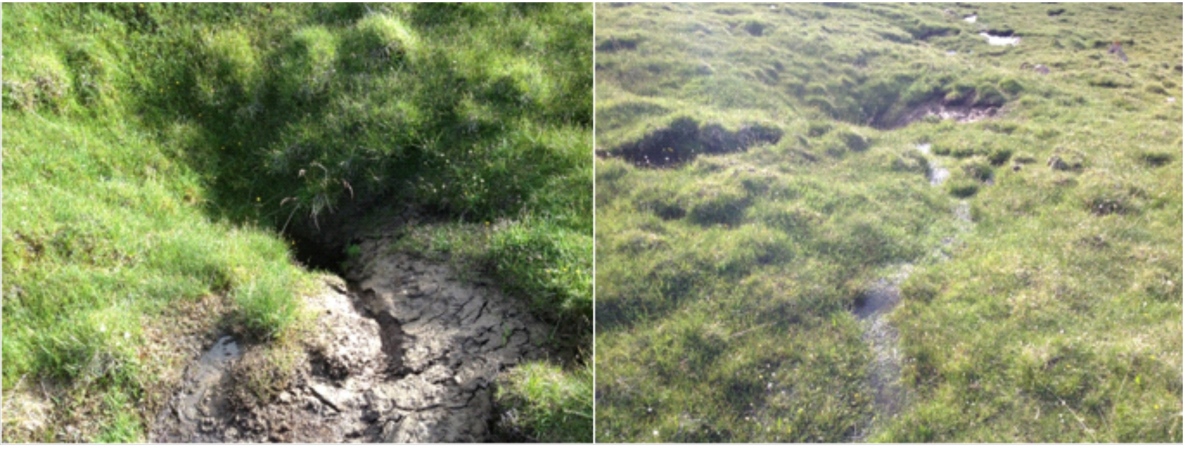

(a)

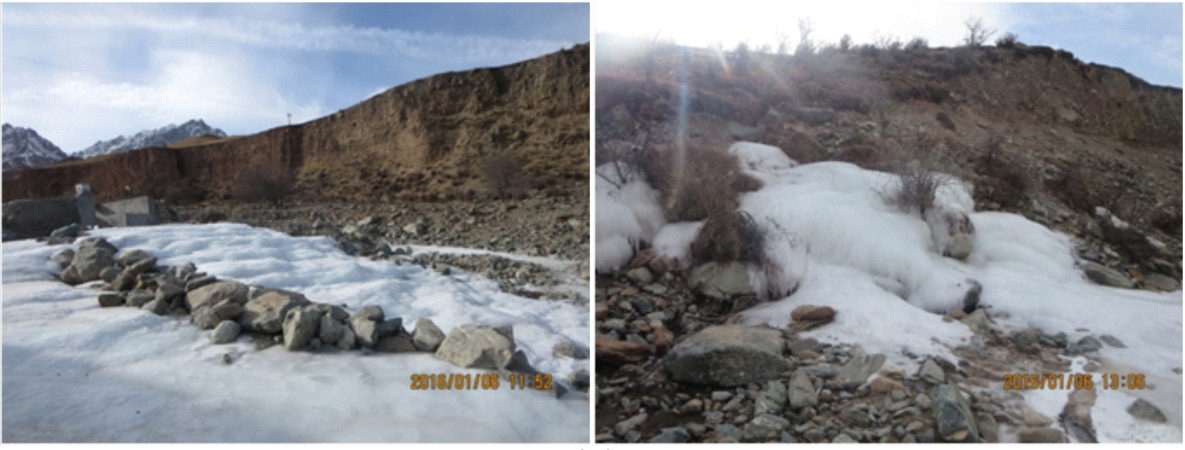

(b)

Figure 11. Pictures showing (a) sinkholes in the permafrost zone, (b) stream icing within the gorge (left) and spring icing on the hill slope (right) during cold season.

ermafrost groundwater samples, suggesting that this second recharge source was glacier and snow meltwater (Fig. 8).

The thick unconsolidated sediment, consisting of highly permeable moraine and fluvioglacial sediments, was continuously deposited from the front of glacier to the lowest terrace on the top of the hill, and a continuous, slightly sloping subpermafrost porous aquifer is expected. Thus, we hypothesize that glacier meltwater recharged to the subpermafrost aquifer mainly at localized water bodies such as glacier-fed headwater streams and lakes on the moraines and then traveled for a long horizontal distance in the aquifer to the lowest terrace where cluster WW04 is located. Although the subpermafrost aquifer underlies the $20 \mathrm{~m}$ thick permafrost, the water table below the bottom of permafrost indicated that the subpermafrost groundwater was unconfined, which is an indicator of poor recharge and/or good discharge of groundwater (Zhang et al., 2011). As the hydrogeological setting is relatively favorable for the recharge of subpermafrost groundwater in the warm season, it must have a comparable discharge capacity. The sediment and ground temperatures data show that the subpermafrost aquifer is mainly composed of unconsolidated sandy gravels and pebbles with high permeability (Figs. 3 and 5), facilitating fast flow and thus groundwater discharge. In addition, the interface between unconsolidated sediments and underlying bedrock may also serve as an efficient passage for subpermafrost groundwater discharge (Woo, 2012).

There is a distinct break in sediment composition and thickness between the planation surface and the adjacent three hill slopes. With the thinning of the moraine and fluvioglacial sediments, the subpermafrost porous aquifer disappears over the impermeable bedrock or thin residues at the upper slopes. Thus, like the suprapermafrost groundwater, the subpermafrost groundwater was mainly discharged directly into streams as baseflow, or onto the surface as seeps and springs at the upper portions of the hill slopes and then into streams. This is probably why several ground and spring icings can be found on the slopes during cold seasons (Fig. 11b).

The recharge and discharge of the subpermafrost groundwater mainly occurred in the warm season, and were limited in the cold season. However, the starting time of discharge was earlier than the recharge time whereas the end times were reversed due to the altitude difference between recharge sources and discharge exits. This would reduce subpermafrost groundwater storage in early autumn and later spring and illuminate why the subpermafrost groundwater table declined significantly in cold season. 


\subsubsection{Intrapermafrost groundwater}

The ground temperatures in the talik where intrapermafrost groundwater occurred were similar to those in the adjacent permafrost, being $\sim 0{ }^{\circ} \mathrm{C}$ throughout the year (Fig. 5). Thus, the localized presence of this unfrozen cold groundwater may be related to its high mineralization $\left(\sim 1059 \mathrm{mgL}^{-1}\right.$ in TDS). The TDS and the concentrations of major cations, minor elements ( $\mathrm{Si}$ and $\mathrm{Sr}$ ), $\mathrm{HCO}_{3}^{-}$and $\mathrm{Cl}^{-}$in intrapermafrost groundwater were much higher than in sub- and suprapermafrost groundwater and thermokarst pond water (Fig. 7b), excluding the mixture of these water sources. However, the intrapermafrost groundwater was depleted in ${ }^{2} \mathrm{H}$ and ${ }^{18} \mathrm{O}$ and fell near the LMWL on the $\delta^{2} \mathrm{H}$ vs. $\delta^{18} \mathrm{O}$ plot (Fig. 8), indicating a modern meteoric water origin without significant evaporation. These results suggest that intrapermafrost groundwater experienced a long-term water-rock interaction in a closed environment. The well logs show that this talik was rich in organic matter. Given the very low $\mathrm{SO}_{4}^{2-}\left(4.1 \mathrm{mgL}^{-1}\right)$ and much higher $\mathrm{HCO}_{3}^{-}$concentration $\left(833.6 \mathrm{mg} \mathrm{L}^{-1}\right)$ in the intrapermafrost groundwater, sulfurization may have occurred in the reservoir (Domenico and Schwartz, 1998). The hydrochemical and isotopic data prove that this talik was closed and possessed strong reducibility, and also suggest that the intrapermafrost groundwater had a poor hydraulic connection with supra- and subpermafrost groundwaters.

\subsection{Exchange and pathways of groundwater in seasonal frost zone}

\subsubsection{Groundwater at the top of the piedmont sloping plain}

The water table was always higher in the $20 \mathrm{~m}$ well than in the $30 \mathrm{~m}$ well within cluster WW03, and in both wells it fluctuated in response to heavy rainfall events and stream discharge pulses during the warm season. This suggests that the groundwater at the top of the piedmont sloping plain was recharged by local stream infiltration since the deep water table excluded the possibility of vertical rainfall infiltration. This conclusion was confirmed by the concave upward profiles of temperature at cluster WW03 in the warm season (Fig. 5). However, the $\delta^{2} \mathrm{H}$ and $\delta^{18} \mathrm{O}$ values of groundwater were relatively constant over time and showed little response to rainfall or stream discharge pulses (Fig. 10c), indicating that the isotopic signals might be diluted by lateral inflows from high mountain and hill areas to the groundwater at the top of the plain.

The combined groundwater table, temperature, and hydrogeochemical and isotopic data suggest that three sources may contribute to the lateral inflows. Two sources, supraand subpermafrost groundwater, occurred in deposits on the planation surfaces of the higher hills which connect to the southeastern top of the piedmont sloping plain. As discussed above, they discharged onto hill slopes as seeps and springs and flowed down the slopes as surface runoff or flowed through the weathered slope residues as subsurface runoff and, finally, moved as lateral flow into the aquifer at the top of the sloping plain. The third source was the suprapermafrost groundwater and surface runoff generated in the bedrock mountains which are connected to the southern top of the piedmont sloping plain. In the bedrock mountains, suprapermafrost groundwater occurred only within the surficial fissures and weathered zones, and the amounts were limited (Cao, 1977), whereas surface runoff was assumed to be abundant due to the steep slopes and low permeability of the area (Chen et al., 2014). Much of this shallow subsurface and surface runoff flowed into streams while a small fraction of it may flow through talus fans at the base of mountains and, finally, into the aquifer at the top of the sloping plain. The limited storage and rapid flow of this recharge source resulted in significant responses of the water table at the top of the plain to heavy rainfall events, while the mixture of runoff generated at different altitudes minimized the fluctuation of $\delta^{2} \mathrm{H}$ and $\delta^{18} \mathrm{O}$ values in groundwater.

The lateral inflows into the plain occurred mainly during the warm season, as indicated by ground temperature and water table data. As talus consists of gravel and boulders that are more permeable than mud-bearing pebble gravels in the plain (Xu et al., 1989), the lateral flow from the mountains may accumulate at the top of the plain, leading to the increase in the water table and thus decreased the difference in the water table between the talus of the mountain and the top of the plain. As a result, the aquifer at the top of the plain was dominated by lateral flow with a small vertical component. It addresses the distinct peaks in the water table several days after heavy rainfall events and the small difference in groundwater hydraulic head between the 20 and $30 \mathrm{~m}$ wells within cluster WW03 during the warm season (Fig. 4). Over the cold season from November to June, the lateral inflow decreased and even ceased, but the groundwater stored during the warm season was still released slowly to the base of the plain. As a consequence, the water table at the top of the plain declined dramatically and the phreatic surface between mountain foot talus and the top of the plain became steeper. Therefore, the groundwater flow had a larger vertical downward component, explaining the increased difference in water head between the 20 and $30 \mathrm{~m}$ wells within cluster WW03 during the cold season (Fig. 4). The lateral recharge from permafrost groundwater was probably continuous until October, as suggested by the water table change. The switch of the water table dynamic in cluster WW03 from falling to rising in May marked the beginning of lateral recharge in a new annual cycle. This is consistent in time with the thaw of the active layer indicated by ground temperature data at cluster WW04 (Fig. 5) 


\subsubsection{Groundwater at the base of the piedmont sloping plain}

The almost invariable groundwater table at cluster WW01 during either the warm or cold season was the typical characteristic of groundwater in discharge areas. Along the flow path from cluster WW03 to WW01, major ions and TDS concentrations increased, and the enrichment of ${ }^{2} \mathrm{H}$ and ${ }^{18} \mathrm{O}$ isotopes in groundwater was expected (Clark and Fritz, 1997). However, the groundwater had more negative $\delta^{2} \mathrm{H}$ and $\delta^{18} \mathrm{O}$ values at cluster WW01 than at cluster WW03 (Fig. 8), which suggests the mix of an isotopically depleted water source when groundwater flowed through the plain. The local rainfall infiltration can be excluded according to the recent research on water balance in the plain, which reported that the thick vadose zone and high transpiration prevented precipitation from entering the aquifer (Chen et al., 2014). From June to September when the stream water was fed by isotopically depleted glacier meltwater and thus had more negative $\delta^{2} \mathrm{H}$ and $\delta^{18} \mathrm{O}$ values, groundwater exhibited the similar depleted trend in ${ }^{2} \mathrm{H}$ and ${ }^{18} \mathrm{O}$, strongly suggesting the recharge from stream infiltration (Figs. 8 and 10). The recharge of this "new" water source also explains the very young age of groundwater at cluster WW01, inferred by ${ }^{3} \mathrm{H}$ concentration (Table 2).

As described above, the piedmont sloping plain is funnelshaped, with only a narrow gorge at the base leading to the Heihe River. The eastern and western tributaries converged into the main Hulugou stream in front of the gorge, which then was contained within the gorge (Fig. 1b). Since the gorge is surrounded by hills that are composed of less permeable shales and sandstones, and unconsolidated deposits were only found on the bottom of the gorge, groundwater was blocked in front of the gorge with the narrowing of the flow cross section and discharged mainly as baseflow along the main stream or as springs at the foot of the hills (Fig. 1b). This is similar to the "fill and spill" mechanism in hillslope hydrology (Spence and Woo, 2003; Tromp-van Meerveld and McDonnell, 2006) and addresses the relatively high and stable water table in the warm season at cluster WW01 (Fig. 5). The water tables in the 5 and $10 \mathrm{~m}$ wells at cluster WW01 were close to each other in the warm season and higher than those in the 15 and $25 \mathrm{~m}$ wells. This may be related to the continuous clay layer at depth of 13-18 m and suggests two flow paths in the aquifer. Given that the groundwater flow within the gorge was consistent with the streamflow in the horizontal direction, the shallow groundwater was discharged into the upper portions of the main Hulugou stream, while the deep groundwater drained into the lower portions (Fig. 12).

The discharge of groundwater to the stream was indicated by the similar chemical compositions between the stream water and groundwater during the cold season, and the discharge process was complicated by the development of stream icing and seasonal frost. Our data show that all trib- utaries were dry throughout the cold season and river icing was only found in the main Hulugou stream channel within the gorge (Fig. 11b). Icing was initially formed in the upper reaches of the stream channel in early winter, followed by continued thickening and downstream expansion in winter and early spring. Meanwhile, icing was also formed at the spring near the plain-hill border. Field investigation in January 2015 showed that the upper reaches of the stream channel were completely filled with ice and no water was flowing under it. The frozen streambed exerted hydrostatic pressure on the groundwater. The maximum depth of the seasonal frost in the gorge should be $3 \mathrm{~m}$, deduced from the temperature data at cluster WW01 (Fig. 5). Considering that the main stream was sustained completely by baseflow in winter, the groundwater depth along the stream channel (bottom of the gorge) should be shallow and probably $<1 \mathrm{~m}$. Thus, the seasonal freezing would reach the water table in early winter and also exerted pressure on groundwater, resulting in the confined condition in the unconsolidated sediment aquifer within the gorge. When groundwater flowed from the phreatic aquifer in the open plain to this tilted confined aquifer, it would have a larger vertical downward component, causing the larger difference in the water head between the 5,10,15 and $20 \mathrm{~m}$ wells within cluster WW01 in the cold season (Fig. 4). At the lower reaches of the stream channel with water flowing under ice, the icing constricted the channel cross section and exerted hydrostatic pressure on stream water, also significantly reducing groundwater discharge into the channel (Kane, 1981). This may be another reason for the relatively stable water table at the base of the open plain in the winter. The more negative $\delta^{2} \mathrm{H}$ and $\delta^{18} \mathrm{O}$ values in the stream water compared to its source groundwater indicates a strong isotopic fractionation between the river icing and stream water (Souchez and Jouzel, 1984).

\subsection{Conceptual model of the groundwater exchange and pathways}

Based on the geochemical, thermal, isotopic and hydrological results, a conceptual model of the hydrological connectivity in the mountain-hill-plain complex was developed (Fig. 12). Groundwater in the high mountains mainly occurred as suprapermafrost groundwater within either moraine and scree deposits or surficial fissures in bedrock outcrop areas. In the moraine and fluvioglacial deposits on the planation surfaces of higher hills (about $>3500$ ma.s.l.), supra, intra- and subpermafrost groundwaters cooccurred. There were three hydrological passages through which glacier and snow meltwater and precipitation were transported from the high mountains to the plain. The first and fastest one was the stream channel, which generally originated at the glacier front and was fed by glacier and snow meltwater in its head. Then it was recharged by overland flow and suprapermafrost groundwater over its course from the mountains to the piedmont sloping plain, and also probably by subpermafrost 


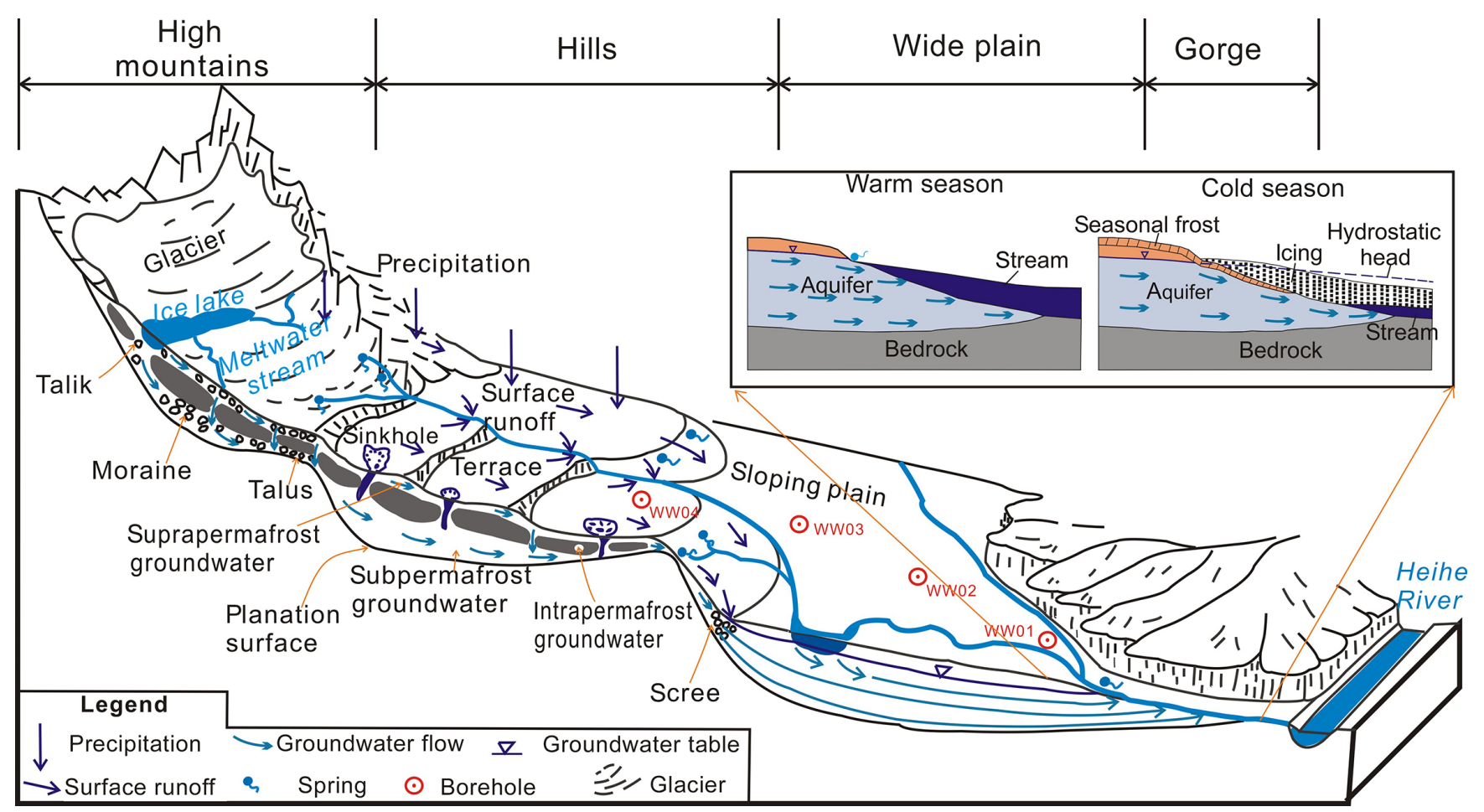

Figure 12. Conceptual model of groundwater exchange and pathways in the Hulugou catchment.

groundwater at the foot of hill slopes. The stream percolated partly down into the aquifers when flowing through the open plain, and was recharged by groundwater when flowing through the gorge. This passage was available only during the warm season and dried up during the cold season. The second passage was the slope surface and suprapermafrost aquifer, which collected precipitation over a large area, then transported much of it as overland flow and suprapermafrost groundwater into talus fans at the foot of mountains or hills, and finally into the aquifer at the top of the plain. Where the moraine and scree deposits in high mountains adjoin the moraine and fluvioglacial deposits on higher hills, the glacier and snow meltwater may also be transported through this passage after flowing through moraine and scree deposits at the lower margin of cirques. This passage was also seasonal. The third passage was the subpermafrost aquifer occurring on the planation surface, through which the recharged glacier and snow meltwater that percolated down over the moraines within cirques flowed to the hill slopes, and finally into the aquifer at the top of the plain. The water within the second passage also added into this passage through supra- and subpermafrost connections on the planation surface. The third passage was the slowest one, but also the only one that was available during the cold season.

The porous aquifer in the piedmont plain was mainly recharged by the lateral flow from the southern mountains and hills and the seepage of streams, and discharged mainly as baseflow to the stream in the northern gorge. The water table dynamics at the top of the plain were characterized by sharp rises and recessions in response to heavy rainfall events but a gradual decline during the cold season, while those at the base of the plain exhibited a stable trend confined to a narrow range. This behavior indicates a rapid transfer of groundwater from the southern top to the northern base of the plain during the warm season and a slow release of stored groundwater during the cold season. It suggests that the groundwater in the plain not only contributed significantly to streamflow during the warm season, but also maintained streamflow over the cold season. We propose two mechanisms involved in the significant seasonal variation of the aquifer in waterconduction capacity, which were surface drainage through the stream channel and subsurface drainage to an artesian aquifer confined by stream icing and seasonal frost (Fig. 12). The first mechanism was similar to "fill and spill" in hillslope hydrology (Spence and Woo, 2003; Tromp-van Meerveld and McDonnell, 2006) and involved the funnel-shaped distribution of unconsolidated permeable deposits in the plain. When groundwater flowed from the wide plain to the gorge, the cross section narrowed down, leading to a decrease in transmissivity and an uplifted water table. This kept the water table in front of the gorge from dropping below the channel bed, thus maintaining continuous flowing in the downstream channel throughout the year. However, the unchecked surface drainage through the stream channel prevented the water table from rising too high after storms in the rainy season. This mechanism explains the rapid transfer of groundwater from 
the top to the base of the plain and the stable water table in front of the gorge during the warm season. The second mechanism worked only during the cold season, when the stream icing and seasonal frost converted the aquifer in the gorge from unconfined to a confined condition. The rise of the downstream groundwater head reduced the hydraulic gradient between the wide plain and the gorge, resulting in decreased discharge. In addition, the increased icing constricted the channel cross section while the descending frost reduced the effective thickness of saturated soil, significantly decreasing groundwater discharge into the channel. This mechanism illuminated the slow release of stored groundwater from the plain and thus the gradual decline of the water table at the top of the plain during the cold season.

\section{Conclusions}

Groundwater studies in permafrost areas are challenging because of limited infrastructure and a short field season. These conditions favor the use of geochemical and isotopic tracers in baseflow and perennial springs to supplement hydrogeological data to elucidate recharge conditions and flow paths. By selecting a representative catchment in the headwater regions of the Heihe River in the Qinghai-Tibet Plateau as a study site, this research employed the groundwater head, temperature, geochemical and isotopic information to determine the roles of groundwater in permafrost and seasonal frost zones in hydrologically connecting the waters originating from glaciers in the high mountains to the lower elevation streams.

Our field measurements show the cooccurrence of supra-, intra- and subpermafrost groundwaters in the headwater regions of the Heihe River. To the best of our knowledge, this is the first report of the occurrence of sub- and intrapermafrost groundwaters in this region. The moraine and fluvioglacial deposits on the planation surfaces of higher hills, which are commonly distributed in the headwater regions of the Heihe River, provide a major reservoir for the storage and flow of sub- and intrapermafrost groundwater. The subpermafrost groundwater on the planation surface was interconnected to the surface hydrological processes and recharged by suprapermafrost groundwater and glacier and snow meltwater. The results of this study could shed new light on the understanding of the groundwater flow and its interaction with surface water in other catchments, as well as improve the evaluation and management of water resources in the headwater regions of the Heihe River.

Glacier and snow meltwater were transported from the high mountains to the plain through stream channels, slope surfaces, and supra- and subpermafrost aquifers. The groundwater in the piedmont plain within seasonal frost zones was mainly recharged by the lateral flow from the supra- and subpermafrost aquifers and the seepage of streams, and was discharged as baseflow into the Hulugou stream in the northern gorge. A rapid transfer of groundwater from the southern top to the northern base of the plain occurred during the warm season, while the stored groundwater was slowly released during the cold season. This seasonal variation of the aquifer in water-conduction capacity was interpreted by two mechanisms. The first is surface drainage via the stream channel, analogous to the "fill and spill" mechanism in hillslope hydrology. The narrowing of aquifer from the wide plain to the gorge led to a relatively high water table near the gorge, preventing it from dropping below the channel bed and maintaining a perennial flow in the downstream. This addresses the rapid transfer of groundwater from the top to the base of the plain and the stable water table in front of the gorge during the warm season. The second is subsurface drainage to an ephemeral artesian aquifer confined by stream icing and seasonal frost. The stream icing and seasonal frost not only blocked the groundwater discharge, but also changed the bottom of the gorge into a confined aquifer during the cold season, leading to an increase in the downstream groundwater head and a decrease in the hydraulic gradient between the wide plain and the narrow gorge. The second mechanism elucidates the slow release of stored groundwater from the plain and the low baseflow in channel throughout the cold season.

Data availability. The data of geology, precipitation, air temperature, hydrogeochemistry, isotope, monthly groundwater table depth and temperature are available at the WestDC database (http:// westdc.westgis.ac.cn/). The hourly water table depth and groundwater temperature data are available on request.

Competing interests. The authors declare that they have no conflict of interest.

Acknowledgements. This research was financially supported by the National Natural Science Foundations of China (no. 91325101 , 91125009, and 41521001).

Edited by: Bill $\mathrm{Hu}$

Reviewed by: Sihai Liang and two anonymous referees

\section{References}

Anderson, L., Birks, J., Rover, J., and Guldager, N.: Controls on recent Alaskan lake changes identified from water isotopes and remote sensing, Geophys. Res. Lett., 40, 3413-3418, 2013.

Bense, V. F. and Person, M. A.: Transient hydrodynamics within intercratonic sedimentary basins during glacial cycles, J. Geophys Res.-Earth, 113, F04005, https://doi.org/10.1029/2007JF000969, 2008.

Bense, V. F., Ferguson, G., and Kooi, H.: Evolution of shallow groundwater flow systems in areas of degrading permafrost, Geophys. Res. Lett., 36, L22401, https://doi.org/10.1029/2009GL039225, 2009. 
Cao, J.: The Report of Regional Hydrogeological Survey in Ye'niutai (J-47-(16)) $(1: 200,000)$, Unit 00926 of the Chinese People's Liberation Army (CPLA), 70 pp., 1977.

Carey, S. K. and Quinton, W. L.: Evaluating runoff generation during summer using hydrometric, stable isotope and hydrochemical methods in a discontinuous permafrost alpine catchment, Hydrol. Process., 19, 95-114, 2005.

Carey, S. K. and Woo, M. K.: The role of soil pipes as a slope runoff mechanism, Subarctic Yukon, Canada, J. Hydrol., 233, 206-222, 2000.

Chen, R. S., Song, Y. X., Kang, E. S., Han, C. T., Liu, J. F., Yang, Y., Qing, W. W., and Liu, Z. W.: A cryosphere-hydrology observation system in a small alpine watershed in the Qilian Mountains of China and its meteorological gradient, Arct. Antarct. Alp. Res., 46, 505-523, 2014.

Cheng, G. and Jin, H.: Permafrost and groundwater on the QinghaiTibet Plateau and in northeast China, Hydrogeol. J., 21, 5-23, 2013.

Clark, I. D. and Fritz, P.: Environmental Isotopes in Hydrogeology, CRC Press/Lewis Publishers, Boca Raton, Florida, USA, 1997.

Domenico, P. A. and Schwartz, F. W.: Physical and Chemical Hydrogeology, John Wiley and Sons, Inc., New York, USA, 1998.

Evans, S. G., Ge, S. M., and Liang, S. H.: Analysis of groundwater flow in mountainous, headwater catchments with permafrost, Water Resour. Res., 51, 9564-9576, 2015.

Frey, K. E., Siegel, D. I., and Smith, L. C.: Geochemistry of west Siberian streams and their potential response to permafrost degradation, Water Resour. Res., 43, W03406, https://doi.org/10.1029/2006WR004902, 2007.

Ge, S. M., McKenzie, J., Voss, C., and Wu, Q. B.: Exchange of groundwater and surface-water mediated by permafrost response to seasonal and long term air temperature variation, Geophys. Res. Lett., 38, L14402, https://doi.org/10.1029/2011GL047911, 2011

Gran, G.: Determination of the equivalent point in potentiometric titrations. Part II, Analyst, 77, 661-671, 1952.

Han, D. M., Kohfahl, C., Song, X. F., Xiao, G. Q., and Yang, J. L.: Geochemical and isotopic evidence for palaeo-seawater intrusion into the south coast aquifer of Laizhou Bay, China, Appl. Geochem., 26, 863-883, 2011.

Jones, B. M., Grosse, G., Arp, C. D., Jones, M. C., Anthony, K. M. W., and Romanovsky, V. E.: Modern thermokarst lake dynamics in the continuous permafrost zone, northern Seward Peninsula, Alaska, J. Geophys. Res.-Biogeo., 116, G00M03, https://doi.org/10.1029/2011JG001666, 2011.

Kane, D. L.: Physical mechanics of aufeis growth, Can. J. Civil. Eng., 8, 186-195, 1981.

Kane, D. L., Yoshikawa, K., and McNamara, J. P.: Regional groundwater flow in an area mapped as continuous permafrost, NE Alaska (USA), Hydrogeol. J., 21, 41-52, 2013.

Li, Z. X., Feng, Q., Liu, W., Wang, T. T., Cheng, A. F., Gao, Y., Guo, X. Y., Pan, Y. H., Li, J. G., Guo, R., and Jia, B.: Study on the contribution of cryosphere to runoff in the cold alpine basin: A case study of Hulugou River Basin in the Qilian Mountains, Global Planet. Change, 122, 345-361, 2014.

Minsley, B. J., Abraham, J. D., Smith, B. D., Cannia, J. C., Voss, C. I., Jorgenson, M. T., Walvoord, M. A., Wylie, B. K., Anderson, L., Ball, L. B., Deszcz-Pan, M., Wellman, T. P., and Ager, T. A.: Airborne electromagnetic imaging of dis- continuous permafrost, Geophys. Res. Lett., 39, L02503, https://doi.org/10.1029/2011GL050079, 2012.

Mook, W. G.: Carbon-14 in hydrogeological studies, in: The Terrestrial Environment, A, edited by: Fritz, P. and Fontes, J. C., Handbook of Environmental Isotope Geochemistry, Elsevier, Amsterdam, the Netherlands, 1980.

O’Donnell, J. A., Jorgenson, M. T., Harden, J. W., McGuire, A. D., Kanevskiy, M. Z., and Wickland, K. P.: The effects of Permafrost thaw on soil hydrologic, thermal, and carbon dynamics in an Alaskan peatland, Ecosystems, 15, 213-229, 2012.

Pearson, F. J. and Hanshaw, B. B.: Sources of dissolved carbonate species in groundwater and their effects on carbon-14 dating, in: Proceedings of A Symposium on Isotope Hydrology, International Atomic Energy Agency, Vienna, Austria, 1970.

Plug, L. J., Walls, C., and Scott, B. M.: Tundra lake changes from 1978 to 2001 on the Tuktoyaktuk Peninsula, western Canadian Arctic, Geophys. Res. Lett., 35, L03502, https://doi.org/10.1029/2007GL032303, 2008.

Smith, S. D., Wellington, A. B., Nachlinger, J. L., and Fox, C. A.: Functional responses of riparian vegetation to streamflow diversion in the Eastern Sierra Nevada, Ecol. Appl., 1, 89-97, 1991.

Souchez, R. A. and Jouzel, J.: On the Isotopic Composition in Delta-D and Delta-O-18 of Water and Ice during Freezing, J. Glaciol., 30, 369-372, 1984.

Spence, C. and Woo, M.-k.: Hydrology of subarctic Canadian shield: soil-filled valleys, J. Hydrol., 279, 151-166, 2003.

Sternberg, L. D. L., Deniro, M. J., and Savidge, R. A.: Oxygen isotope exchange between metabolites and water during biochemical reactions leading to cellulose synthesis, Plant Physiol., 82, 423-427, 1986.

Stotler, R. L., Frape, S. K., Ruskeeniemi, T., Ahonen, L., Onstott, T. C., and Hobbs, M. Y.: Hydrogeochemistry of groundwaters in and below the base of thick permafrost at Lupin, Nunavut, Canada, J. Hydrol., 373, 80-95, 2009.

Tamers, M. A.: Validity of radiocarbon dates on groundwater, Surv. Geophys., 2, 217-239, 1975.

Tong, J., Zhou, M., Sun, Z., Chang, Q., and Li, J.: Water vapor sources of precipitation in the upper reaches of Heihe River: Evidence from stable water isotopes and air mass trajectory model (in Chinese), J. Arid Land Resour. Environ., 30, 151-156, 2016.

Tromp-van Meerveld, H. J. and McDonnell, J. J.: Threshold relations in subsurface stormflow: 2. The fill and spill hypothesis, Water Resour. Res., 42, W02411, https://doi.org/10.1029/2004WR003800, 2006.

Utting, N., Lauriol, B., Mochnacz, N., Aeschbach-Hertig, W., and Clark, I.: Noble gas and isotope geochemistry in western Canadian Arctic watersheds: tracing groundwater recharge in permafrost terrain, Hydrogeol. J., 21, 79-91, 2013.

Vogel, J. C.: Investigation of groundwater flow with radiocarbon, in: Proceedings of A Symposium on Isotope in Hydrology, International Atomic Energy Agency, Vienna, Austria, 1967.

Vogel, J. C.: Carbon-14 dating of groundwater, in: Proceedings of A Symposium on Isotope Hydrology, International Atomic Energy Agency, Vienna, Austria, 1970.

Vogel, J. C. and Ehhalt, D.: The use of carbon isotopes in groundwater studies, in: Proceedings of A Symposium on Radioisotopes in Hydrology, International Atomic Energy Agency, Vienna, Austria, 1963. 
Vonk, J. E., Tank, S. E., Bowden, W. B., Laurion, I., Vincent, W. F., Alekseychik, P., Amyot, M., Billet, M. F., Canario, J., Cory, R. M., Deshpande, B. N., Helbig, M., Jammet, M., Karlsson, J., Larouche, J., MacMillan, G., Rautio, M., Anthony, K. M. W., and Wickland, K. P.: Reviews and syntheses: Effects of permafrost thaw on Arctic aquatic ecosystems, Biogeosciences, 12, 7129-7167, 2015.

Walvoord, M. A. and Striegl, R. G.: Increased groundwater to stream discharge from permafrost thawing in the Yukon River basin: Potential impacts on lateral export of carbon and nitrogen, Geophys. Res. Lett., 34, L12402, https://doi.org/10.1029/2007GL030216, 2007.

Walvoord, M. A., Voss, C. I., and Wellman, T. P.: Influence of permafrost distribution on groundwater flow in the context of climate-driven permafrost thaw: Example from Yukon Flats Basin, Alaska, United States, Water Resour. Res., 48, W07524, https://doi.org/10.1029/2011WR011595, 2012.

White, D., Hinzman, L., Alessa, L., Cassano, J., Chambers, M., Falkner, K., Francis, J., Gutowski, W. J., Holland, M., Holmes, R. M., Huntington, H., Kane, D., Kliskey, A., Lee, C., McClelland, J., Peterson, B., Rupp, T. S., Straneo, F., Steele, M., Woodgate, R., Yang, D., Yoshikawa, K., and Zhang, T.: The arctic freshwater system: Changes and impacts, J. Geophys. Res.Biogeo., 112, G04S54, https://doi.org/10.1029/2006JG000353, 2007.
Woo, M.-K.: Permafrost Hydrology, Springer, Berlin, 2012.

Woo, M.-K., Kane, D. L., Carey, S. K., and Yang, D.: Progress in permafrost hydrology in the new millennium, Permafrost Periglac., 19, 237-254, 2008.

$\mathrm{Xu}, \mathrm{Z}$., Liu, S., and Chen, Y.: The Report of Geological Survey in the Dalangnongsi Brigade (J-47-68-B) and Qilian County (J47-69-A) $(1: 50,000)$, The 5th Unit of No.2 Geological Team of Qinghai Province, the People's Republic of China, 211 pp., 1989.

Yoshikawa, K. and Hinzman, L. D.: Shrinking thermokarst ponds and groundwater dynamics in discontinuous permafrost near Council, Alaska, Permafrost Periglac., 14, 151-160, 2003.

Zhai, Y., Wang, J., Guo, H., Cao, Y., and Teng, Y.: Reconstruction and optimization of tritium time series in precipitation of Beijing, China, Radiocarbon, 55, 67-79, 2013.

Zhang, R., Liang, X., Jin, M., Wan, L., and Yu, Q.: Fundamentals of Hydrogeology, Geological Publishing House, Beijing, 2011.

Zhang, X., He, J., Zhang, J., Polyakov, I., Gerdes, R., Inoue, J., and $\mathrm{Wu}, \mathrm{P}$. : Enhanced poleward moisture transport and amplified northern high-latitude wetting trend, Nature Clim. Change, 3, 47-51, 2013. 